\title{
The Cetaceans of Ghana, a Validated Faunal Checklist
}

\author{
K. Van Waerebeek ${ }^{1 * 3}$, P. K. Ofori-Danson ${ }^{2,1}$ and J. Debrah ${ }^{1,4}$ \\ ${ }^{1}$ Conservation and Research of West African Aquatic Mammals (COREWAM-Ghana), P. O. Box LG99, \\ EcoLab, University of Ghana, Legon, Ghana; \\ ${ }^{2}$ Department of Oceanography and Fisheries, University of Ghana, P. O.Box LG99, Legon, Ghana; \\ ${ }^{3}$ Centro Peruano de Estudios Cetológicos (CEPEC), Museo de Delfines, Pucusana, Lima 20, Peru; \\ ${ }^{4}$ Department of Fisheries and Aquatic Sciences, University of Cape Coast, Cape Coast, Ghana \\ *Corresponding author; E-mail: etnunquam@yahoo.co.nz
}

\begin{abstract}
The cetaceans of Ghana and the Gulf of Guinea have, until recently, remained unstudied. Periodical monitoring of artisanal fisheries for bycatches in seven Ghanaian artisanal fishing ports and landing sites over 1996-2004 has provided photographic and specimen evidence to validate occurrence of 18 species (17 odontocetes, 1 mysticete) in a tropical, predominantly pelagic cetacean fauna. At least nine species and subspecies had not previously been documented for Ghana (with asterisk), and four species are authenticated for the first time in the Gulf of Guinea (double asterisk), i.e. Tursiops truncatus, Stenella clymene, S. longirostris longirostris*, S. attenuata, S. frontalis, Delphinus capensis capensis*, Lagenodelphis hosei, Steno bredanensis, Grampus griseus, Peponocephala electra*, Feresa attenuata**, Globicephala macrorhynchus, Orcinus orca*, Pseudorca crassidens*, Kogia sima**, Physeter macrocephalus*, Ziphius cavirostris** and Megaptera novaeangliae. Also, the limited published information on distribution, natural history and conservation status is critically reviewed for each taxon. Indications are that most species encountered off Ghana may be widely distributed in the Gulf of Guinea, most notably the long-beaked common dolphin. The vulnerable Atlantic humpback dolphin, Sousa teuszii, remains unrecorded in Ghana and neighbouring nations despite apparently suitable coastal habitat. It is suggested that localized extinction may be blamed, possibly the result of accumulative bycatches and disturbance. A number of other cetacean species not yet encountered could occasionally occur in Ghana's waters, e.g. Balaenoptera brydei, Mesoplodon densirostris, Kogia breviceps, Stenella coeruleoalba and Delphinus delphis.
\end{abstract}

\section{Introduction}

Despite extensive 20th century whaling in equatorial Africa, primarily in waters of northern Namibia, Angola, Gabon and Congo (e.g. Budker, 1951, 1953; Best, 1994; Best et al., 1999), the cetacean fauna of the Gulf of Guinea and the tropical eastern Atlantic south of it, and, especially the small odontocetes, have scarcely been studied. A substantiated faunal checklist of cetacean species, while an essential zoogeographical tool, is lacking for most coastal nations bordering the Gulf of Guinea, including Ghana. Some cetacean guidebooks offer entirely hypothetical distribution maps for the region which can lead to undue conclusions. For example, the distribution of the Atlantic humpback dolphin, Sousa teuszii, a taxon endemic to the region, is often shown as continuous along West African coasts, notwithstanding recent field evidence pointing to wide distribution hiatuses throughout its range (Van Waerebeek, 2003; Van Waerebeek et al., 2004; Collins et al., 2004).

Scant earlier reports of cetaceans in Ghanaian waters (Irvine, 1947) were either unidentified to species, unsupported, or both. Ofori-Adu (1987) recalls a whale, estimated to be over $15 \mathrm{~m}$, stranded at Sekondi beach, Akuburam, near the lighthouse of the Sekondi-Takoradi beach road, on 19 November 1975. A whale surfaced around the stationary ship RN Kakadiamaa for 45 min during a dermersal fish trawling survey cruise, off the Saltpond oil rig in March 1985 (Ofori-Adu 1987). An unidentified captured dolphin was seen at Dixcove in May 1988 by F. X. Baird (pers. comm. in Maigret, 1994). 'Some' marine mammal mortality was reported to occur in the pelagic fishery with pirogues and purse-seiners (Maigret, 1994).

In 1999, a preliminary Ghana cetacean checklist, presented to the International Whaling Commission, reported six species (Van Waerebeek \& Ofori-Danson, 1999). Debrah's (2000) master's dissertation, while focusing on fisheries interactions, added a few more species. In an overview of bycatches in 1998-2000, Ofori-Danson et al. (2003) reported 14 cetacean species, taken off Ghana's coast, the source used by Perrin \& Van Waerebeek (2007) to table Ghana as range state for these species. However, in these papers few, if any, species validation and other biological findings were included.

The present work provides for the first time a comprehensive compilation and fully validated checklist of the 18 cetacean species encountered in Ghana's marine waters. Most of the new information resulted from exploratory land-based field research and port monitoring intended to evaluate the ongoing exploitation and demonstrate the need for a systematic nation-wide data collection scheme.

\section{Material and methods}

The core study area, $c a .510 \mathrm{~km}$ east-west extending coast of Ghana (Fig. 1), oceanographically forms part of the Gulf of Guinea, defined as the large open arm of the tropical eastern Atlantic, formed by the great bend of the coast of West Africa, including the Bight of Benin and the Bight of Biafra (Bight of Bonny). The Gulf of Guinea (abbreviated as 'the Gulf') is bordered on the southwest by a line running southeastward from Cape

West African Journal of Applied Ecology, vol. 15, 2009 
Palmas (Harper) in eastern Liberia, near the border with La Côte d'Ivoire ( $04^{\circ} 21.4^{\text {' }} \mathrm{N}, 07^{\circ} 31.6^{\prime}$ W) to Cape López ( $0^{\circ} 38^{\prime}$ S, $08^{\circ} 42^{\prime}$ E), Gabon (International Hydrographic Organization, 1953). It encompasses 10 coastal nations: (eastern) Liberia, La Côte d’Ivoire, Ghana, Togo, Benin, Nigeria, Cameroon, Equatorial Guinea (including Bioko but not Annobón Islands); (northern) Gabon, and São Tomé and Principe. Three major river systems, the Volta, Niger and Gabon rivers, drain into it

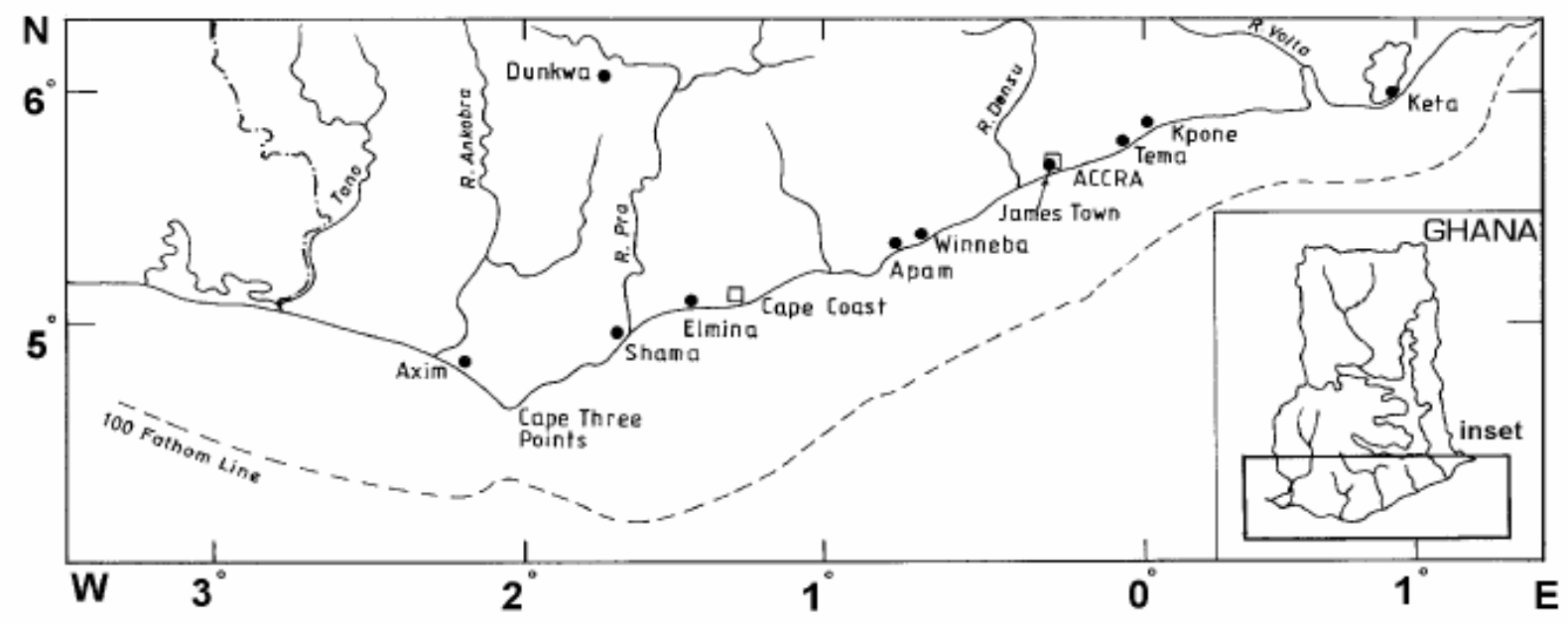

Fig. 1. Map of the coast of Ghana with localities (mainly ports and fish landing beaches) as mentioned in the text. The 100 fathom line $(183 \mathrm{~m})$ depth contour indicates the limit of the continental shelf.

The local surface flow is dominated by the eastward Guinea Current, accompanied by a westward undercurrent (Adamec \& O’Brien, 1978). Koranteng (2001) sum-marized Ghana's oceanography regime briefly as follows: a subsystem of the Guinea Current Large Marine Ecosystem, the continental shelf waters off Ghana experience two seasonal periods of coastal upwelling (major and minor) each year, with differing duration and intensities. During the upwelling, sea surface temperature (SST) drops, surface salinity increases, and dissolved oxygen decreases. The major upwelling of nutrient-rich water (long cold season) occurs between July and September when SST (usually 27-29 ${ }^{\circ} \mathrm{C}$ ) falls below $25^{\circ} \mathrm{C}$. The minor upwelling (short cold season) normally lasts for only about 3 weeks (occurring anytime between December and March). In between the cold seasons are warm seasons during which SST is relatively high and a strong thermocline is formed in continental shelf waters.

Adequate documentation of the occurrence of cetacean species in Ghana is a primary base-line for marine mammal studies as well as for their management. Sources included mainly freshly dead animals landed as bycatch or direct take, stranded carcasses, opportunistic sightings, and some skeletal material archived at marine biological collections. A comprehen-sive literature review yielded very little substantiation. The authors and trained local observers monitored Ghana's ports periodically between 1998-2003, directed initially from the Water Research Institute (Council for Scientific and Industrial Research, Accra) and, subsequently, from the Department of Oceanography and Fisheries, University of Ghana, Legon. Most specimens were examined or photographed at seven artisanal fishing ports and fish landing beaches, from west to east (Fig. 1): Axim ( $\left.04^{\circ} 51.3^{\prime} \mathrm{N}, 02^{\circ} 13.5^{\prime} \mathrm{W}\right)$, Dixcove (04 $\left.48^{\prime} \mathrm{N}, 01^{\circ} 57^{\prime} \mathrm{W}\right)$, Shama $\left(05^{\circ} 01^{\prime} \mathrm{N}\right.$,

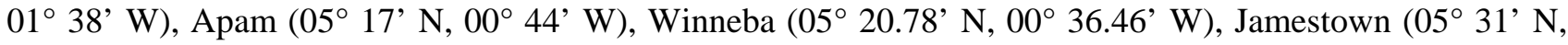
$00^{\circ} 13^{\prime} \mathrm{W}$ ) and Tema ( $\left.05^{\circ} 38^{\prime} \mathrm{N}, 00^{\circ} 01^{\prime} \mathrm{E}\right)$. Capture locations and habitat type (neritic, slope, pelagic), however, are unknown, as artisanal fishermen may operate both to the north of, and beyond Ghana's (ca. 40 km wide) continental shelf.

The checklist documents the earliest positive records in Ghana for each species and reviews its distribution, natural history and conservation status in the Gulf. Where data were lacking, occurrence closest to the study area, chiefly in the tropical eastern Atlantic south of the Gulf, was examined, however, without attempting to review all of western Africa. Voucher material, such as field notes, photographs depicting diagnostic characteristics and (unpublished) project reports, are archived as part of COREWAM's 'Ghana Cetacean Data-base'. Osteological material and tissue samples, kept in saturated saline solution of dimethylsalfoxide (DMSO) for molecular genetics studies, are kept at the University of Ghana (UOG), Legon.

Body/carcass condition codes agree with Geraci \& Lounsbury (1993); briefly: (1) alive, (2) very fresh and suitable for human consumption, (3) early decomposition, (4) advanced decomposition, (5) exposed bones or mummified. Where condition is not indicated it was ' 2 '. Point-to-point distances between locations were West African Journal of Applied Ecology, vol. 15, 2009 
computed with GPS software MapSource 6.4 (Garmin Cor-poration, 2004). Abbreviations for tooth/alveoli counts are lower left (LL), lower right (LR), upper left (UL) and upper right (UR).

\section{Checklist}

Delphinidae

Common bottlenose dolphin, Tursiops truncatus

Earliest documented records. Two freshly captured common bottlenose dolphins were landed by a purseseiner at Jamestown on 5 February 1994 (Fig. 2). One, a 300-cm male, was necropsied at CSIR and its skull, scapulae, four vertebrae (including atlas and axis), os hyale, partial sternum, one rib, one humerus and ulna, several teeth and a tissue sample (in DMSO) were collected. A second and a third common bottlenose dolphin, of $255 \mathrm{~cm}$ and $315 \mathrm{~cm}$ length, were brought ashore at Senya Beraku $\left(05^{\circ} 23^{\prime} \mathrm{N}, 00^{\circ} 29^{\prime} \mathrm{W}\right)$ and Tema, respectively. These dolphins were previously reported but equivocally assigned to Delphinus delphis (Ofori-Danson \& Odei, 1997). A calvaria dredged by a fishing boat from an indeterminate site in Ghana's shelf waters, collected by Dr Ofori-Adu sometime before 1998, was identified by KVW at the Tema Research and Utilization Branch of the Fisheries Department (Ministry of Agriculture).

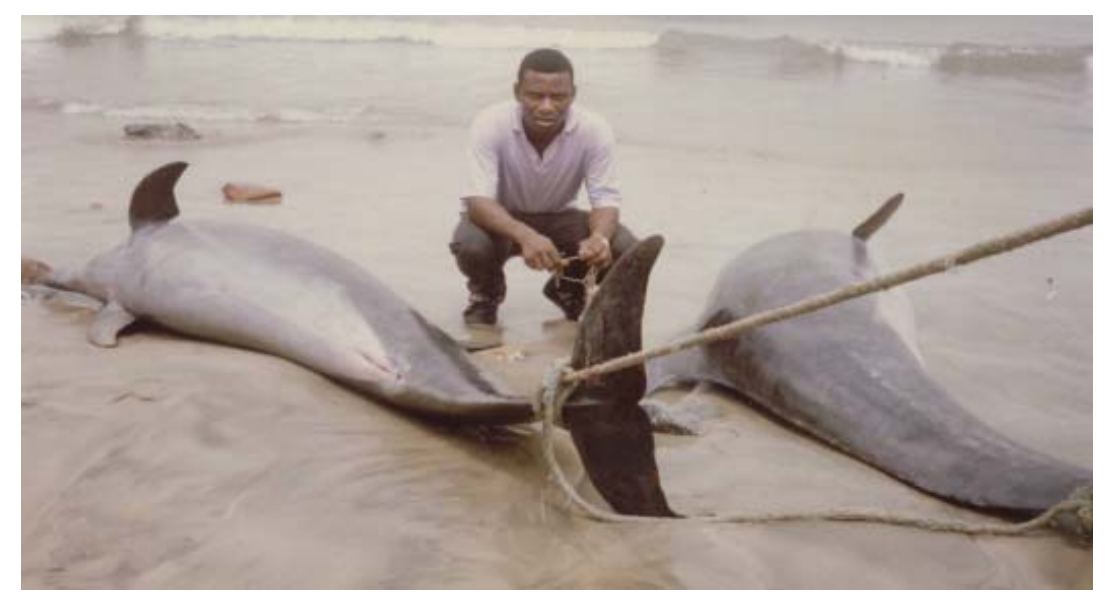

Fig. 2. Two common bottlenose dolphins, Tursiops truncates, pulled up the beach by artisanal fishermen at Jamestown, near Accra, on 5 Feb 1994.

Distribution and natural history. Common bottlenose dolphins have positively been recognized both east and west of Ghana. A small group was seen foraging around artisanal encircling gillnets set in very nearshore waters, just west of Cotonou, Benin (Van Waerebeek, pers. observations). Four bottlenose dolphins taken 10$16 \mathrm{~nm}$ south of Vridi (estimated location $c a .05^{\circ} 14.5^{\prime} \mathrm{N}, 04^{\circ} 02.3^{\prime} \mathrm{W}$ ), Ivory Coast, in April, June and December 1957-1958 (Cadenat \& Lassarat, 1959a) belonged to an indeterminate stock, possibly offshore. In May 1999, KVW measured four T. truncatus subadult skulls (USNHM 470551, 470554, 470555, 470556) at the US National History Museum, which originated from Abidjan, Ivory Coast; but no other data were on record. Both inshore and offshore populations of common bottlenose dolphins occur off Angola year-round (Weir, 2007), as well as off western South Africa and Namibia (Ross, 1977; Findlay et al., 1992). In Ghana, a body mass of $265 \mathrm{~kg}$ was registered for a $300-\mathrm{cm}$ physically adult male and $280 \mathrm{~kg}$ for a 295-cm female. Five specimens from La Côte d'Ivoire ranged 233-272 cm in length (Cadenat, 1959). Four stomachs examined contained anchovies, shrimp, small scombrids, sardines and cephalopods (Cadenat \& Lassarat, 1959a), suggesting an opportunistic feeding ecology. Cadenat (1959) argued, based on known habitat for some of the prey species, that bottlenose dolphins might dive and forage at depths over $200 \mathrm{~m}$.

Conservation status. T. truncatus is the third most frequently (15.5\%) landed small cetacean in Ghana (Ofori-Danson et al., 2003). The location of the usual drift-gillnetting grounds suggests an offshore stock, although this has not been morphologically or genetically confirmed. An adult individual, landed at Dixcove on 2 December 2001, bled profusely from a piercing wound on the throat, as from a directed kill. Five common bottlenose dolphins were taken by harpoongun, at least partly for research, by La Côte d'Ivoire's Service des Pêches Maritimes, off Vridi, Abidjan, in 1957-58 (Cadenat \& Lassarat, 1959). A total of 11 livecapture attempts were made in Walvis Bay, Namibia, in 1975, 1976 and 1983 (Findlay et al., 1992). Best \& Ross (1984) warned against capture operations of small coastal populations of T. truncatus on South Africa's west coast as 'potentially of more consequence, as these populations are probably much smaller and may be more localised than the other, more pelagic species.' For the same reasons Van Waerebeek et al. (2008) 
advised against a proposal of exploitation of inshore bottlenose dolphins without proper assessment in Guinea-Bissau.

\section{Clymene dolphin, Stenella clymene}

Earliest documented records. Ghanaian fishermen are most familiar with the Clymene dolphin, sometimes calling it the 'true dolphin' or 'Etsui Papa' because the species is so frequently found entangled in fishing gear. A probable bycatch specimen from Keta (05 55' N, 00 59' E) in May 1956 (Prof. Chris Gordon, pers. communication) is the earliest specimen record in the Gulf. The physically mature skeleton is mounted (without number) in the Zoology Department museum at UOG (alveoli counts, 41UL, 42 LL). A second specimen, a 216-cm female, with sharply pointed teeth (38UL, 39LL), was captured off Winneba on 23 September 1998 (Fig. 3). The tripartite body colouration, including a white belly, black eye patch, grey eyeto-flipper stripe, a characteristic dark stripe along the middle of the upper rostrum ending in a black rostrum tip, and fine blackish lip patches were evident (Perrin et al., 1981). A third, juvenile, specimen (99/03) was landed at Apam on 20 July 1999 (its head was shown as Plate B in Ofori-Danson et al., 2003). No helminth parasites were found in the cranial sinus system. Since then a total of 13 cranial specimens has been collected from bycatches, now archived at UOG (98/01; 98/02; 98/03; 98/04; 98/05; 98/06; 98/07; 98/09; 98/11; 99/02; 99/03; 20/09B; 20/036).

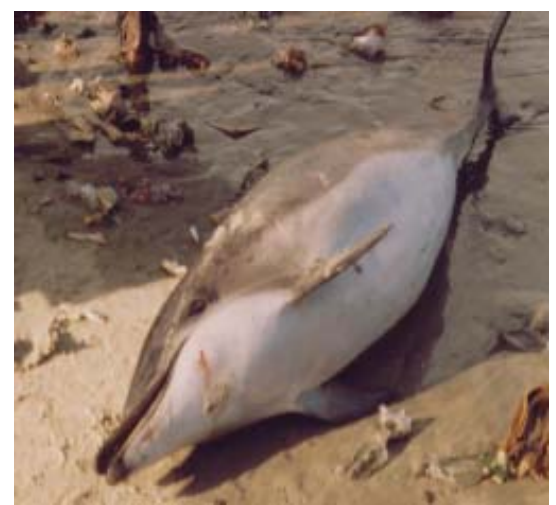

Fig. 3. The Clymene dolphin, Stenella clymene, is the most frequently landed cetacean in Ghana. Shown here is a freshly dead specimen, captured off Winneba.

Distribution and natural history. A sighting in deep oceanic water at $02^{\circ} 10^{\prime} \mathrm{N}, 02^{\circ} 30^{\prime} \mathrm{W}$, some $160 \mathrm{~nm}$ south off Axim port, equivocally assigned to $S$. longirostris (Leatherwood et al., 1976), was recognized as $S$. clymene (Perrin et al., 1981; Robineau et al., 1994). From temporal distribution of captures, Clymene dolphins appear to be present year-round in Ghanaian waters. South of the Gulf, credible sightings were recently reported from Congo and Angola (Weir, 2006a, 2007). As expected, the species is absent from the cool Benguela system off southwestern Africa (Findlay et al., 1992).

Jefferson (2002), in reviewing the species (mostly western Atlantic records), found scant information on its natural history. Of three animals examined from Apam, two had forestomachs infested with, respectively, 213 and 40 anisakid nematodes (Debrah, 2000).

Conservation status. Based on port monitoring from 1998-2000, 34.5\% of captured cetaceans were Clymene dolphins, more than of any other species (Ofori-Danson et al., 2003). Most catches were by driftgillnet fishermen operating out of Apam and Dixcove. The COREWAM-Ghana database holds photographic evidence for at least 35 net-entangled specimens. In March 2007, concern about the observed take, which likely underestimates the true scale of removals in the Gulf, led the CMS Scientific Council to unanimously endorse an Appendix II listing proposal for the West African stock (Van Waerebeek, 2007). CMS Appendix II lists 'migratory species which have an unfavourable conservation status and which require international agreements for their conservation and management, as well as those which have a conservation status which would significantly benefit from the international cooperation that could be achieved by an international agreement' (Article IV, CMS Convention). See http://www.cms.int/documents/index.htm

Pantropical spinner dolphin, Stenella longirostris longirostris (Perrin, 1990)

Earliest documented records. OD collected the heads of two spinner dolphins landed at Dixcove, a cranially mature 197-cm individual (DOF 20/01; 19 June 2000) and a 190-cm specimen (DOF 20/038; 26 Oct 2000). Third and fourth specimens were sampled (DOF 20/028 and DOF 20/004, Fig. 4) at Axim on 8 Nov 2000 and on an indeterminate date in 2000, respectively. The four skulls are archived at UOG.

West African Journal of Applied Ecology, vol. 15, 2009 


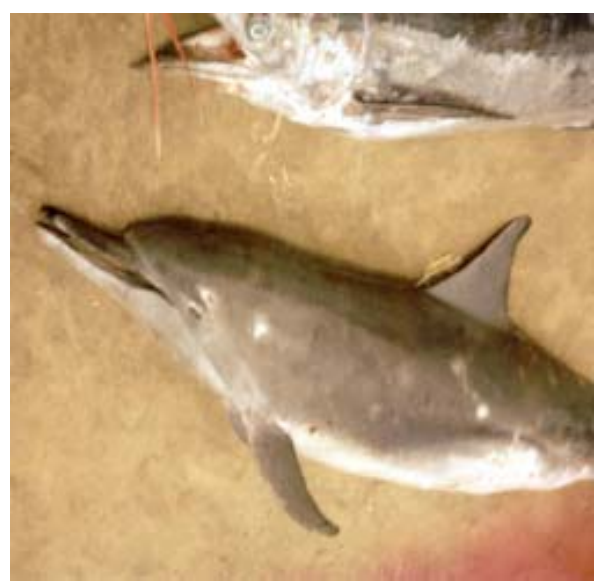

Fig. 4. Pantropical spinner dolphin, Stenella longirostris longirostris, encountered at Axim in 2000. Diagnostic characters include the very elongated rostrum, dark-tipped dorsally, triangular and pointed dorsal fin, small flippers and the three-partite patterned body (dark cape, grey lateral field, white ventral field).

Distribution and natural history. Three other specimens are documented from the region. These include a specimen from La Côte d'Ivoire (van Bree, 1971), a skull (CBL $414 \mathrm{~mm}$ ) from a 188-cm female, archived at the US National History Museum (USNM470557) and examined by Van Waerebeck on 14 May 1999, which originated from Abidjan, La Côte d'Ivoire, and another skull from Liberia curated at the Leiden Natural History Museum (Broekema, 1983). S. longirostris, typically wide-ranging oceanic dolphins, are likely to occur throughout deeper waters of the eastern tropical Atlantic. Weir (2007) reported sightings in deep pelagic areas off Angola.

Conservation status. The slightly falcate (nearly triangular on some adults) dorsal fin, standard tripartite colouration (Fig. 4) and the large adult body lengths $(n=2)$, which fall within the 180-215 cm range (Perrin, 1990), suggest the subspecies S. longirostris longirostris, pending confirmation from further data. Conservation status is unknown. Spinner dolphins are only infrequently captured (3.5\% of dolphin takes) by Ghana's artisanal fishermen (Ofori-Danson et al., 2003) which is consistent with a preferred habitat of deep waters. Industrial tuna fishing, associated with dolphins in the tropical eastern Atlantic, is very 'unequally' distributed (Fonteneau \& Marcille, 1993). In fact, the oft proffered claim that tuna-dolphin associations are rare in this ocean province and, therefore, tuna purse-seiners rarely set upon dolphins (Maigret, 1981, 1994; Fonteneau \& Marcille, 1993; Donahue \& Edwards, 1996), stands in sharp contrast with the situation in the eastern tropical Pacific (e.g. Perrin, 2004) and is only feebly supported.

Fonteneau \& Marcille (1993) warn 'all these results are to be considered with care, from the fact of the restrained number of observations of sets associated with dolphins'. Bycatch self-reporting schemes, even if mandatory, such as logbook schemes, often result in substantial under-reporting (Northridge, 1996). Even some observer schemes with trained onboard technicians may not be fully independent from the fishing industry and associated stakeholders. If the captures by small-scale drift-gillnet boats in Ghana are any indication, several species of tuna, billfish and sharks are habitually taken with dolphins in the same nets (Debrah 2000; Ofori-Danson et al., 2004.

\section{Pantropical spotted dolphin, Stenella attenuata}

Earliest documented records. The first supported record of $S$. attenuata in Ghana was a juvenile specimen examined at the Apam landing beach in September 1998; the skull (UOG 98/12) was collected. Since then the skulls of another 15 captured individuals (Fig. 5) have been collected, now curated at UOG (98/10; 99/01; 20/005; 20/007; 20/008; 20/08B; 20/009; 20/013; 20/014; 20/015; 20/020; 20/025; 20/026; 20/035; 20/037). 


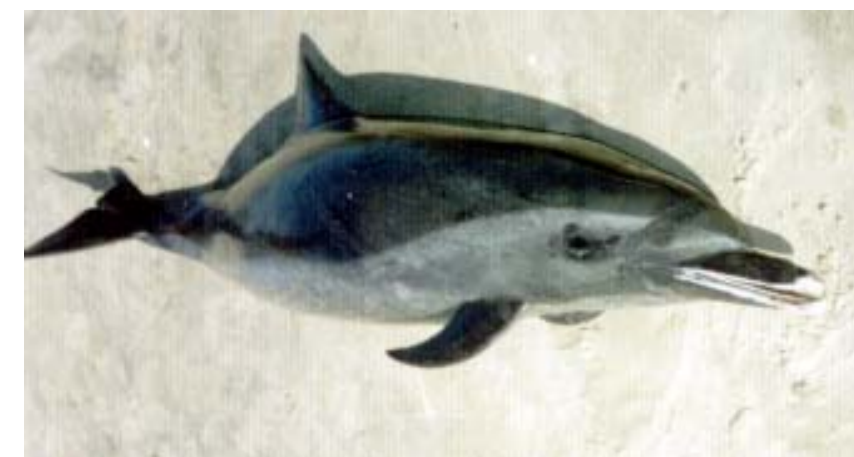

Fig. 5. A fresh pantropical spotted dolphin, Stenella attenuate, landed by Apam fishermen in 1998. Note the brilliant white lips and tip contrasting with an otherwise dark rostrum, the prominent dark cape dipping low onto sides forward of the dorsal fin, grey lateral and ventral fields (with moderate, white spotting), and smallish dark pectoral fins. The gape to flipper stripe is muted in this individual.

Distribution and natural history. In the wider study region, the pantropical spotted dolphin has been documented from La Côte d'Ivoire (Cadenat \& Lassarat, 1959b; van Bree, 1971), Gabon (Fraser, 1950a) and offshore waters of the eastern tropical Atlantic (Perrin et al., 1987). An earlier reference for Ghana (C. W. Oliver, pers. comm. in Jefferson et al., 1997) is not supported by voucher data, but Chuck Oliver, a trained dolphin/tuna observer at the Southwest Fisheries Science Center, La Jolla, California, is considered a trusted source (William F. Perrin, pers. comm.). No records exist from the Atlantic coast of South Africa (Findlay et al., 1992).

On 3 March 1946, 3-4 pantropical spotted dolphins were encountered at $0^{\circ} 15^{\prime} \mathrm{N}, 08^{\circ} 44^{\prime} \mathrm{E} 35 \mathrm{~nm}$ off Pointe Pongara, off the southern shore of the Gabon river estuary (Fraser, 1950a). One animal, a 2-m adult male, was captured, necropsied and morphologically described in great detail and, although reported by Fraser (1950ab) as Stenella frontalis, the nomenclature of spotted dolphins was not fully established until the work by Perrin et al. (1987). Stomach contents included seven decapod cephalopods, six fish, a fragment of a crustacean, lenses of squid and fish, otoliths, squid beaks and nematodes. The blubber contained 'bladder worms', a common name for cestode plerocercoids (Fraser, 1950a). Stomach contents of three pantropical spotted dolphins from Ghana, examined by the authors, revealed that they preyed on herring (Sardinella sp.), anchovy (Engraulis encrasicolus), mackerels, cuttlefish (Sepia sp.) and juvenile octopus. All stomachs were very full, suggesting that the dolphins were netted while feeding or shortly afterwards.

Conservation status. A significant percent-age (17.2\%) of small cetaceans unloaded in Ghana ports were pantropical spotted dolphins, making it the second most frequently captured species in 1998-2000 (OforiDanson et al., 2003). Spinner and pantropical spotted dolphins are the main marine mammal indicator species for the presence of tuna in the eastern tropical Pacific (see annotated review by Perrin, 2004). For large-scale tuna fisheries in the eastern Atlantic such associations have not yet been the subject of rigorous, independent scientific study. Information on levels of incidental dolphin mortality in these fisheries is equally scarce and of questionable credibility.

Atlantic spotted dolphin, Stenella frontalis (G. Cuvier, 1829)

Earliest documented records. The earliest authenticated report of an Atlantic spotted dolphin in Ghana was a juvenile of $175 \mathrm{~cm}$ landed at Dixcove on 19 June 2000. Its skull is curated at UOG (20/01A). A second freshly captured specimen was photographed (Fig. 6) on the Dixcove landing beach on 3 January 2003.

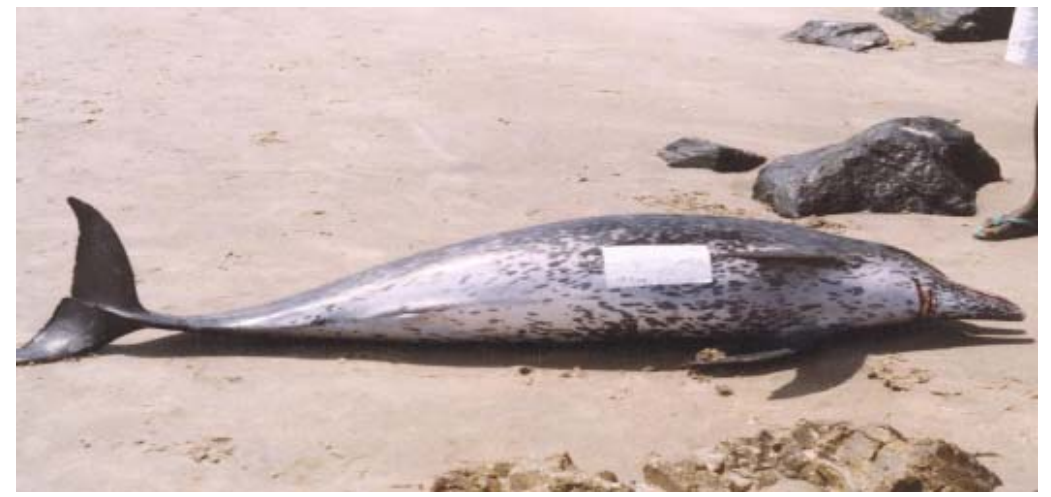

Fig. 6. Atlantic spotted dolphin, Stenella frontalis, offered for sale on Dixcove’s landing beach on 3 Jan 2003. Large black spots on a white ventral field and a sturdy, middle-sized rostrum are characteristic.

West African Journal of Applied Ecology, vol. 15, 2009 
Distribution and natural history. Stenella frontalis is endemic to the eastern and western tropical Atlantic (Perrin et al., 1987). A 188-cm male and a 200-cm female were taken off Vridi, La Côte d'Ivoire, on 28 Feb and 7 March 1958, respectively (Cadenat \& Lassarat, 1959; see Fig. 34-37 in Cadenat, 1959). In Benin’s coastal waters, a group of 10 individuals was sighted, including heavily spotted adults with stocky bodies and big dorsal fins, and unspotted juveniles (Van Waerebeek, 2003). Rice (1998) included Gabon as range state, however, without mentioning his source. Farther south, S. frontalis is reported from sightings off Angola (Weir, 2008), but the species avoids the cold Benguela Current off Namibia and western South Africa (Findlay et al., 1992).

Conservation status. Historically, two specimens were captured for research in La Côte d'Ivoire (Cadenat, 1959). The largest recorded mortality was attributed to fisheries in Mauritania; it involved 140 stranded dolphins (37 of 38 positively identified as S. frontalis) of which at least 125 died (Nieri et al., 1999). In Ghana's fishing ports in 1998-2000, Atlantic spotted dolphins accounted for 5.2\% of the small cetacean bycatch (Ofori-Danson et al., 2003). Off Angola, Weir (2008) detected negative responses to seismic surveying in Atlantic spotted dolphins.

Long-beaked common dolphin, Delphinus capensis capensis (Jefferson \& Van Waerebeek, 2002)

Earliest documented records. Fishermen landed two long-beaked common dolphins of adult size at Dixcove on 18 Oct 1999 (Fig. 7), the species' first confirmed record for Ghana. A third specimen was landed at Axim on 19 June 2000, from which the cranially mature skull was obtained (DOF 20/010). Voucher skulls for another three individuals (DOF 20/02, 20/022, 20/023) were collected by the authors. Cranial features diagnostic of $D$. capensis include a lanceolate- or pseudo-lanceolate-shaped palate (versus trapezoid shape in D. delphis; see Van Waerebeek, 1997) and a high ratio (1.70-1.83) of rostrum length to zygomatic width (Heyning \& Perrin, 1994; Jefferson \& Van Waerebeek, 2002).

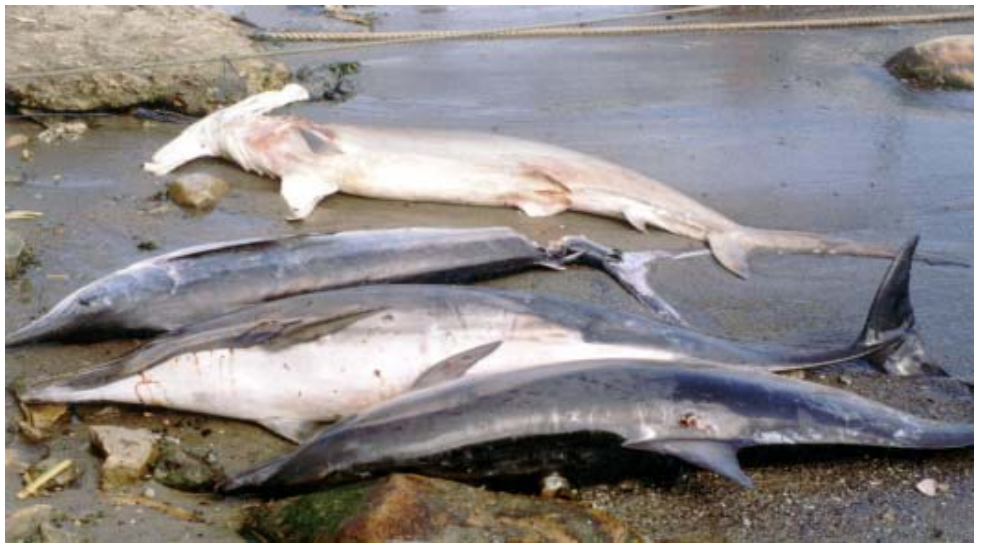

Fig. 7. Two long-beaked common dolphins, Delphinus capensis, landed alongside a smooth hammerhead shark and an unidentified billfish (Istiophoridae) at Dixcove, on 18 Oct 1999. Note the harpoon/lance entry wound at the right side under the dorsal fin of the (lower) dolphin.

Distribution and natural history. Gray (1828) first recognized that the long-beaked common dolphins occurring off South Africa's Cape Province represented a species morphologically distinct from the shortbeaked common dolphin, Delphinus delphis L., known from European seas. After being synonymized with $D$. delphis for most of the 20th century (Hershkovitz, 1966; van Bree \& Purves, 1972; Mitchell, 1975), D. capensis was resurrected and redescribed (Heyning \& Perrin, 1994; Jefferson \& Van Waerebeek, 2002).

For the Gulf, Cadenat (1959ab) published external body measurements for 24 common dolphins (Delphinus delphis) from La Côte d'Ivoire, examined in 1956-58. Tormosov et al. (1980) mapped Delphinus in the Bight of Biafra. A photograph of one specimen (Plate I, Cadenat, 1959) shows head colouration pattern and high relative rostrum length which positively identify it as D. capensis. At the Zoological Museum of Amsterdam (ZMA), Van Waerebeek (1997) re-examined nine West African dolphin skulls considered $D$. delphis (van Bree \& Purves, 1972) but assigned only two specimens to D. delphis, one (ZMA 14.594) from Mayoumba, Gabon and another (ZMA 15.236) from Angola. Four skulls from Gabon (ZMA 14.593, 15.523, 15.522, 15.521), two from Angola (ZMA 14.592, 15.235) and one from Congo (ZMA 15.524) were assigned to D. capensis. Most common dolphins, occurring within the $200 \mathrm{~m}$ isobath shelf in South African waters are D. capensis (Samaai et al., 2005), but there have been (unidentified) common dolphin strandings as far north as Walvis Bay and an incidental capture at $18^{\circ} \mathrm{S}$, confirming their occurrence in Namibia (Findlay et al., 
1992). Two colour morphs have been identified from strandings (Findlay et al., 1992), suggesting both Delphinus spp. may occur there.

Photographs in Rosenbaum \& Collins (2004) of two (p. 34) and six (p. 39) common dolphins, possibly from a single group, show a colouration pattern consistent with that of $D$. capensis, further supporting its presence off Gabon. The mention of Delphinus delphis (Walsh et al., 2000; Rosenbaum \& Collins, 2004) seems to refer to generic common dolphins. The authors suggest that $D$. capensis is widely distributed in coastal waters of the Gulf of Guinea as well as off central Africa (Van Waerebeek, 1997).

Conservation status. A deep piercing dorsal wound in (at least) one of two specimens at Dixcove (Fig. 7) suggests a catch by harpooning or lancing. $D$. capensis is an avid bowrider and can easily be targeted (OforiDanson et al., 2003). Best \& Ross (1977) estimated the combined bycatch of common dolphins and dusky dolphins in purse-seine fisheries for pelagic fish and maasbankers (whiting) off the west and southwest coasts of South Africa and Namibia at 100 animals a year. Common dolphins were also suspected of being handharpooned on the west coast (Best \& Ross, 1977).

\section{Fraser's dolphin, Lagenodelphis hosei}

Earliest documented records. Weir et al. (2008) comprehensively reviewed the species in West Africa. A 140-cm Fraser's dolphin calf, landed in Axim on 21 June 2000, is the earliest validated record for Ghana (Ofori-Danson et al., 2003). Its skull (20/002A) was retrieved for the UOG. Another three bycatch specimens were examined at Dixcove and Axim during 2000 (Debrah, 2000, Fig. 3 and 4 in Weir et al., 2008).

Distribution and natural history. East and SE from Ghana, one 'probable' sighting is documented from Nigeria and two confirmed sightings from Angola (Weir et al., 2008). To the west, the geographically closest record is a skull retrieved at Ile de Sangomar (13 50' N, 16 46' W), Senegal by Van Waerebeek et al. (2000). This suggests that $L$. hosei may be widely distributed in the Gulf of Guinea and the tropical SE Atlantic Ocean. While South Africa is a range state, all records have been from its warm Agulhas-Current-influenced southeast coast (Ross, 1984; Findlay et al., 1992). The natural history of Fraser's dolphin in West Africa has not been studied.

Conservation status. Of unknown status, Fraser's dolphin is only occasionally taken in Ghana's artisanal fisheries, explainable by its preference for deep offshore waters. The potential of bycatches by large pelagic or foreign fishing vessels remains to be assessed.

\section{Rough-toothed dolphin, Steno bredanensis}

Earliest documented records. Artisanal fishermen operating from Apam landed two rough-toothed dolphins in late summer 1998 (date indeterminate either 29 Aug or 24 Sept 1, 1998). Photographic evidence (archived in Corewam's Ghana Cetacean Database) shows the unmistakable conical tapering head and the large, pointed flippers. A third specimen, a juvenile, was offered for sale in Apam on 17 Oct 1999 (photos see Debrah, 2000, p. 33; Van Waerebeek et al., 1999) and a fourth, larger individual (Fig. 8) on 27 Jan 2002, all at Apam. (C. W. Oliver, pers. comm. in Jefferson et al., 1997) reported two undocumented sightings off Ghana in 1972, which, nonetheless, are considered reliable (W. F. Perrin, pers. comm. to Van Waerebeek).

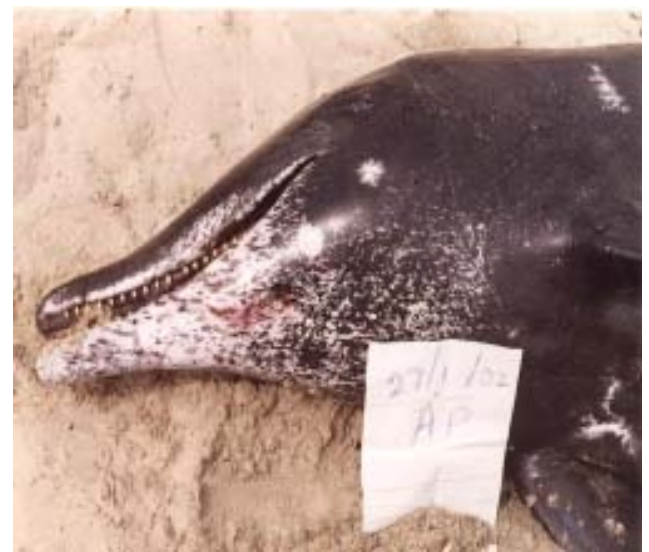

Fig. 8. A rough-toothed dolphin, Steno bredanensis, landed at Apam on 27 Jan 2002. The long-sloping head without melon crease, irregular ventral spotting and large flippers are indicative for this deep-water species.

Distribution and natural history. Rough-toothed dolphins are confirmed from La Côte d'Ivoire by three individuals taken 15-18 nm south of Vridi on 9 May (female), 4 July (male) and 24 Oct (male) 1958 (Cadenat, 1959; Fig. 53, 57-58). The stomachs of at least two specimens from Vridi contained squid and, at 
least, one included fish remains. Two males of $225 \mathrm{~cm}$ and $235 \mathrm{~cm}$ were sexually mature, and a 234-cm female was pregnant with a 70-cm male foetus (Cadenat, 1959). One animal was associated with an SST of $23.5^{\circ} \mathrm{C}$. In May 1999, Van Waerebeek examined a subadult skull (CBL 500-mm) at the US National Museum of Natural History (USNM 0470542) with reported origin 'Abidjan'. Only one specimen record is reported from Namibia, at Möwe Bay (19²0 S, 12 35’ E) in 1986 (Findlay et al., 1992). Rough-toothed dolphins plausibly range in deep waters throughout the eastern tropical Atlantic.

Conservation status. Apparently, the Vridi specimens (Cadenat, 1959) were taken for research purposes. In Ghana, rough-toothed dolphins are occasional victims of gillnet entanglement (3.5\% of cetacean catches). Otherwise, nothing is known on the species' status in the eastern tropical Atlantic.

\section{Risso’s dolphin, Grampus griseus}

Earliest documented records. Fanti fishermen have long been familiar with the Risso's dolphin and call it Eko tui (parrot dolphin). One of the authors (Debrah) sampled a juvenile male Risso's dolphin (99/05) at Apam on 4 Nov 1999. On 16 June 2000, Van Waerebeek and Ofori Danson examined another juvenile male (20/00A) of ca. 2 m length landed at Dixcove (Fig. 9), together with yellowfin tuna (Thunnus albacares), skipjack (Euthynnus pelamis) and indeterminate billfish. Reportedly entangled in a gillnet, it was possibly killed after the net was hauled (deep piercing wound was visible below auditory meatus). The animal carried no phoronts or ectoparasites but its head (collected) showed circular squid sucker scars, suggesting it had at least attempted to prey on squid. A third specimen, pictured in Ofori-Danson et al. (2003), was landed at Axim on 2 Nov 2000.

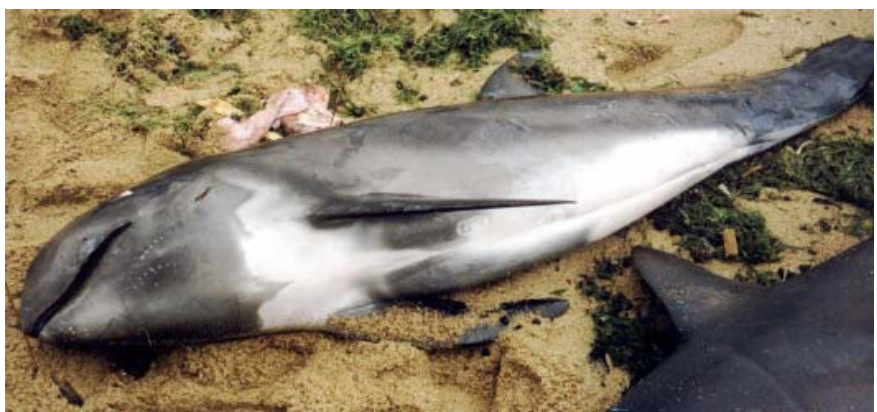

Fig. 9. Risso's dolphin, Grampus griseus, calf at the Dixcove landing beach on 16 Jun 2000. Its flukes had been severed before landing and it was cut in four pieces and sold on the spot.

Distribution and natural history. A crew chased a small group of Risso’s dolphins ca. $25 \mathrm{~nm}$ off La Côte d'Ivoire on 4 July 1958, in a (failed) harpooning attempt. Cadenat (1959) pointed to spots and irregular, white scratches. His figures 65-66 show the characteristic beakless, rounded head and tall, pointed dorsal fin. The species almost certainly occurs throughout the Gulf, but Ghana and La Côte d'Ivoire are the only confirmed range states. The latter record was associated with a SST of $23.5{ }^{\circ} \mathrm{C}$ (Cadenat, 1959). However, the eurythermal G. griseus inhabits tropical to cool-temperate waters, which is in concordance with its presence also off Angola (Weir 2007), Namibia and South Africa, where it is associated with the shelf edge and pelagic waters (Findlay et al. 1992). The forestomach of one specimen (from Axim, 2 Nov 2000) contained at least six anisakid nematodes.

Conservation status. Risso's dolphins are regularly taken (6.9\% of cetacean catches) in Ghana's artisanal fisheries. No other information on status is available.

\section{Melon-headed whale, Peponocephala electra}

Earliest documented records. Photos taken by G. Assefuah of a $250-\mathrm{cm}$ adult female (94/03) with a 122$\mathrm{cm}$ calf landed in Shama in Feb 1994 allowed positive identification. Two further landings were recorded at Dixcove: three animals on 22 June 2000 (Fig. 10) and a single specimen on 18 Jan 2002. The melon-headed whales could positively be distinguished from the morphologically similar pygmy killer whale, Feresa attenuate, by a combination of diagnostic features: a more triangular head in dorsal view (versus more rounded in F. attenuata); a horizontal mouth line (vs markedly inclined from body axis); sharply pointed flippers (vs somewhat rounded at tip) and indications of a face mask pattern. 


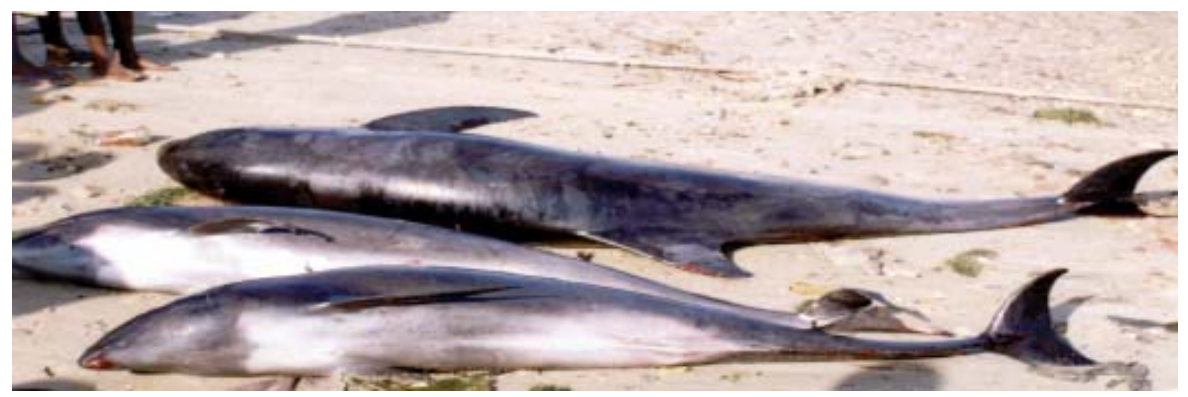

Fig. 10. Three melon-headed whales, Peponocephala electra, landed at Dixcove on 22 Jun 2000. The markedly triangular head-shape (in dorsal view), very pointed flippers, a slender tailstock, an indication of a very short beak (visible in the animal at the forefront) and a higher toothrow count (20-25) distinguishes this species from the pygmy killer whale.

Distribution and natural history. P. electra is known in the Gulf solely from bycatches in Ghana. Geographically, adjacent records are, to the northwest, a skull from Guinea-Bissau (van Bree \& Cadenat, 1968) and to the south, three sightings off Angola in deep oceanic waters (Weir, 2007) plus a stranding at Hout Bay (34 03' S, $\left.18^{\circ} 21^{\prime} \mathrm{E}\right)$, South Africa (Best \& Shaughnessy, 1981). Nonetheless, P. electra may be widely distributed in the eastern tropical Atlantic. Length at birth is reported as ca. $1 \mathrm{~m}$ (Jefferson \& Barros, 1997), but the ' $122 \mathrm{~cm}$ ' calf from Shama showed $4-5$ vertical creases on its flanks, suggestive of foetal folds as from a recent birth. Uncertainty exists though, whether standard length had been taken or body length had been overestimated, by measuring over the body curvature. The Shama female showed swollen mammary slits consistent with lactation, hence it seemed safe to conclude that a mother/calf pair was involved. Female sexual maturity is reached, on average, at $235 \mathrm{~cm}$ (Jefferson \& Barros, 1997), but this does not account for possible geographic variation.

Conservation status. Melon-headed whales are accidentally netted with some regularity in Ghana waters. No other information is available on its status in the Gulf.

Pygmy killer whale, Feresa attenuata

Earliest documented records. An adult-sized pygmy killer whale (Fig. 11) was landed at Dixcove on 31 Dec 2007 and was photographed by fisheries observer, Amiah Johnson.

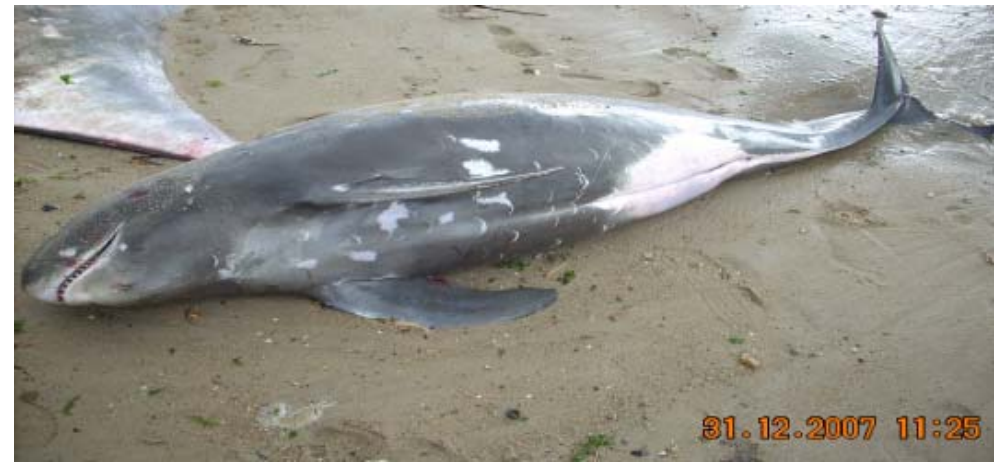

Fig. 11. This adult-sized pygmy killer whale, Feresa attenuata, landed at Dixcove beach on 31 Dec 2007 is the first authenticated record for the Gulf of Guinea. A low count of large, conical teeth and somewhat rounded flipper tips (visible here) sets this species apart from the morphologically similar melon-headed whale.

Distribution and natural history. Pygmy killer whales have not been documented before in the Gulf of Guinea. Records to the south are from Annobon Island (01 24.2' S, $05^{\circ} 36.8^{\prime} \mathrm{E}$ ), attributed by Jefferson et al. (1997) to Tormosov et al. (1980). However, as the reference is unlisted, it was not possible to verify whether it is substantiated. Off southwestern Africa, pygmy killer whales have stranded in Cape Town and as far north as $23^{\circ} \mathrm{S}$, Namibia (Best, 1970; Findlay et al., 1992). Best (1970) documented in great detail four animals stranded at Lüderitz Lagoon, but little other information is published.

Conservation. Pygmy killer whales are only rarely taken by Ghana’s artisanal fisheries.

Short-finned pilot whale, Globicephala macrorhynchus

Earliest documented records. In March 1994, two short-finned pilot whales including a calf were photographed by fisheries officer, D. Vanderpuje, on the landing beach of Shama. Next, a large adult with a pronounced squarish head, very bulbous melon and a huge dorsal fin, was pulled ashore by Axim fishermen on 2 May 1995. Most captured pilot whales are too big to haul onboard artisanal fishing boats and are usually towed to port. At Dixcove, a subadult specimen was sold on 16 June 2000 and an adult with a calf on 16 March 2002 (Fig. 12).

West African Journal of Applied Ecology, vol. 15, 2009 


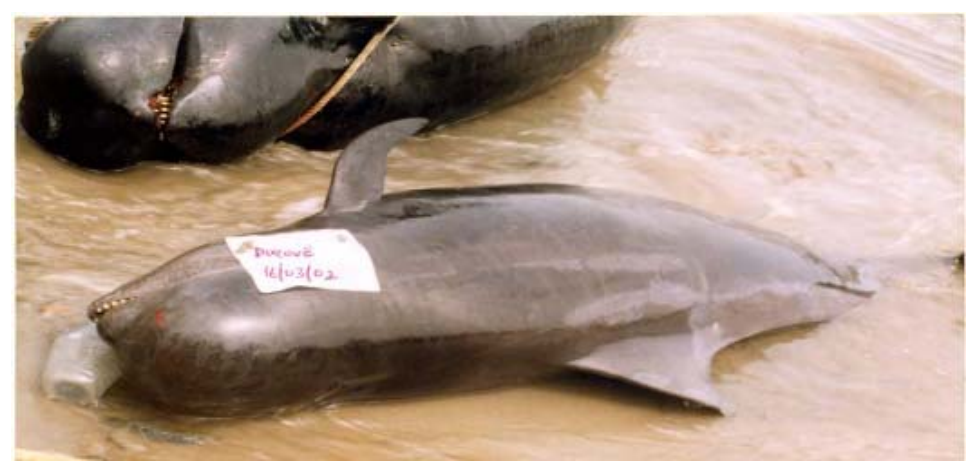

Fig. 12. A calf and an adult short-finned pilot whale, Globicephala macrorhynchus, hauled out at the Dixcove landing beach on 16 Mar 2002.

Distribution and natural history. To the west, G. macrorhynchus is reported from La Côte d'Ivoire waters, authenticated by photographs (figures. 67-68, in Cadenat, 1959). A 312-cm sexually immature female (the smallest individual from a large group) was taken some $8 \mathrm{~nm}$ south of Vridi, on 16 May 1958. Its stomach contained remains of unidentified squid and fish. Other cursory reports relate to unidentified pilot whales in the region. 'Globicéphales' were sighted off Abidjan in Dec 1957 and April and May 1958, but details are lacking (Cadenat, 1959). Pilot whales, Globicephala macro-rhynchus? from near Cap Lopez, Gabon (J. Rouzaud, pers. comm. in Walsh et al., 2000) also cannot be verified. All six specimens examined occurred between March-June. Fraser (1950ab) first summarized the morphology of G. macrorhynchus in NW Africa. Distribution boundaries to the south and southeast are unclear. On South Africa's Atlantic coast the coolwater-adapted long-finned pilot whale, G. melas edwardii, are found but no short-finned pilot whales have been recorded (van Bree et al., 1978; Findlay et al., 1992).

Conservation status. The Vridi specimen was harpooned for research purposes (Cadenat, 1959). Shortfinned pilot whales are irregular bycatch victims (3.5\% of cetacean catches, Ofori-Danson et al., 2003) in drift gillnets off Ghana and are sold for food. A significant conservation problem exists around the Canary Islands. Off Tenerife, damaged dorsal fins and backs, with deep wounds inflicted by small boat propellers, are very common, apparently the result of the carelessness of whale-watchers. In 1990 almost $10 \%$ of short-finned pilot whales were injured by boating (Heimlich-Boran, 1990; Carwardine, 1994; Van Waerebeek et al., 2007).

\section{Killer whale, Orcinus orca}

Earliest documented record. The skull (without catalogue number) of an adult killer whale is held at the Zoology Department, UOG (Fig. 13). According to the curator it has been in the collection for many years, and was collected at an unknown location in Ghana, possibly in 1956. Teeth and corresponding alveoli are oval in cross-section (diagnostic) versus circular as in Pseudorca crassidens.

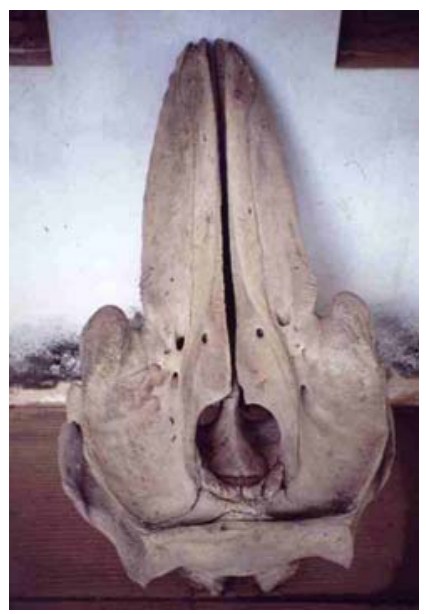

Fig. 13. Skull of a killer whale, Orcinus orca, from an unspecified location in Ghana, curated (without catalogue number) at the University of Ghana, Legon. In dorsal view, the concave lateral borderline of the premaxillaries allows a quick differentiation from the straight and parallel premaxillaries in Pseudorca crassidens. In ventral view, teeth and alveoli are diagnostic.

Distribution and natural history. M.A. Lassarat harpooned a killer whale of unreported size some 15-20 nm south of Abidjan, La Côte d'Ivoire, in late June 1958, but the animal sank before it could be retrieved. Cadenat (1959) claimed that killer whales are regularly present in the region. Given that the species' external 
features are unmistakable, even unauthenticated records may be considered credible. Observers on industrial tuna purse-seiners reported a few sightings off the coast of Liberia, La Côte d'Ivoire and Ghana (records 1-5, Fig. 1 in Hammond \& Lockyer, 1988). Several authors (Reeves \& Mitchell, 1988; C. W. Oliver, pers. comm. to Jefferson et al., 1997) have reported killer whales from Gabon. A photograph taken nearshore (p. 38 in Rosenbaum \& Collins, 2004) clearly shows a medium-sized, horizontally oriented eye-patch and no cape, which agrees with the A-type (O. orca) killer whale of worldwide distribution, and a propensity for a marine mammal diet (Pitman \& Ensor, 2003). The presence of humpback whales with calves in many areas of the Gulf may attract killer whales which are known to prey upon them (e.g. Whitehead \& Glass, 1985). Recent killer whale sightings in Gabon (Rosenbaum \& Collins, 2004) coincide temporarily with the population of humpback whale breeding season. However, killer whales may be present year-round.

Conservation status. The only killer whale, reported taken in the Gulf, was off Abidjan in 1958 (Cadenat, 1959). No captures are on record in Ghana but the skull kept at UOG is possibly derived from a (by)catch. No conservation problems have been identified.

\section{False killer whale, Pseudorca crassidens}

Earliest documented records. Three false killer whales were landed as bycatch at Apam, i.e. two adults on an unspecified date in 2003 (Fig. 14) and a 197-cm juvenile (photo archived) on 24 Sept 2003. The species' presence in Ghana is here documented for the first time.

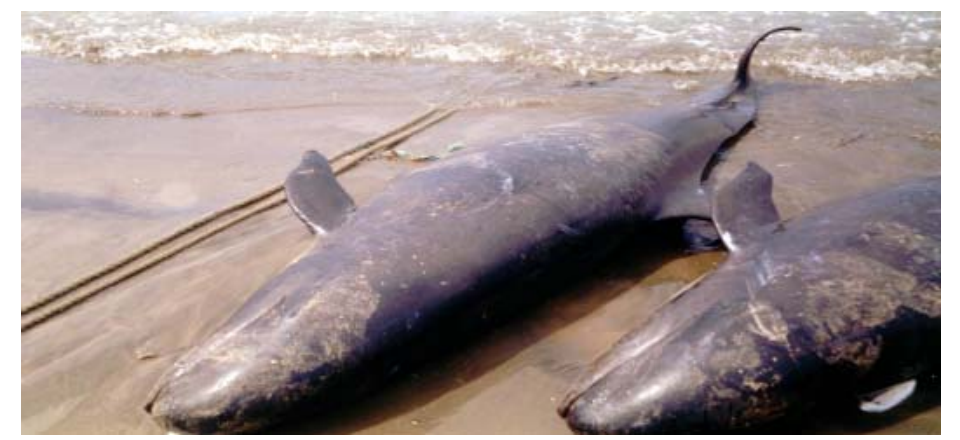

Fig. 14. Two false killer whales, Pseudorca crassidens, landed at Apam in 2003. Combined, the rounded head, almost entirely black colouration, curved flipper shape and the dorsal fin positioned slightly behind mid-back are diagnostic.

Distribution and natural history. A skull, kept at the Zoological Museum, Amsterdam, was collected from a false killer whale stranded near Assini (05 07’25" N, 03 06’40" W), La Côte d'Ivoire, in March 1970 (van

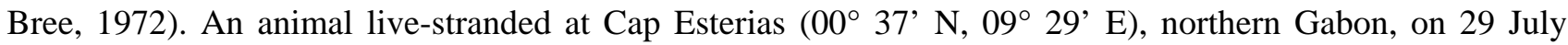
1992, was supported by photos and a description (Van Waerebeek \& De Smet 1996). Van Waerebeek examined the mummified head (tooth counts: UL8, UR8, LL 10, LR10) of an adult false killer whale from Benin at the Direction des Pêches in Cotonou (Van Waerebeek et al., 2001; Tchibozo \& Van Waerebeek, 2007). It had no associated data other than its Benin origin. Mörzer Bruyns (1969) described a group of 30 off Liberia at $04^{\circ} 48^{\prime} \mathrm{N}, 11^{\circ} 24^{\prime} \mathrm{W}$, in water of $28.0^{\circ} \mathrm{C}$ SST on 8 Nov 1961. However, no photos were presented. Nine sightings from Angola in 8 months of the year were all located over deep-water areas seaward of $1467 \mathrm{~m}$ (Weir, 2007), in accordance with the species' usual habitat. Findlay et al. (1992) reported a mass stranding near Lüderitz, Namibia.

Conservation status. The conservation status of P. crassidens in the Gulf is unknown. In Ghana, the species is infrequently captured in drift gillnets. A false killer whale at Cap Esterias, Gabon, stranded again after re-floating and locals then butchered it for food (Van Waerebeek \& De Smet, 1996).

\section{Ziphiidae}

Cuvier's beaked whale, Ziphius cavirostris

Earliest documented record. A freshly captured, 3.2-m Cuvier's beaked whale of indeterminate sex was photographed by D.Vanderpuje at Axim landing beach in May 1994. The juvenile animal (based on its size) had no erupted teeth. Vanderpuje's photographs clearly illustrate the characteristic 'goosebeak' shape of the rostrum (Fig. 15). Tormosov et al. (1980) mapped a Ziphius symbol slightly west of the Greenwich Meridian, just north of the Equator for a sighting in 1976-78 but did not provide any authentication. Therefore, the Axim specimen is the first validated record of $Z$. cavirostris, and of a beaked whale, for Ghana and the Gulf of Guinea. 


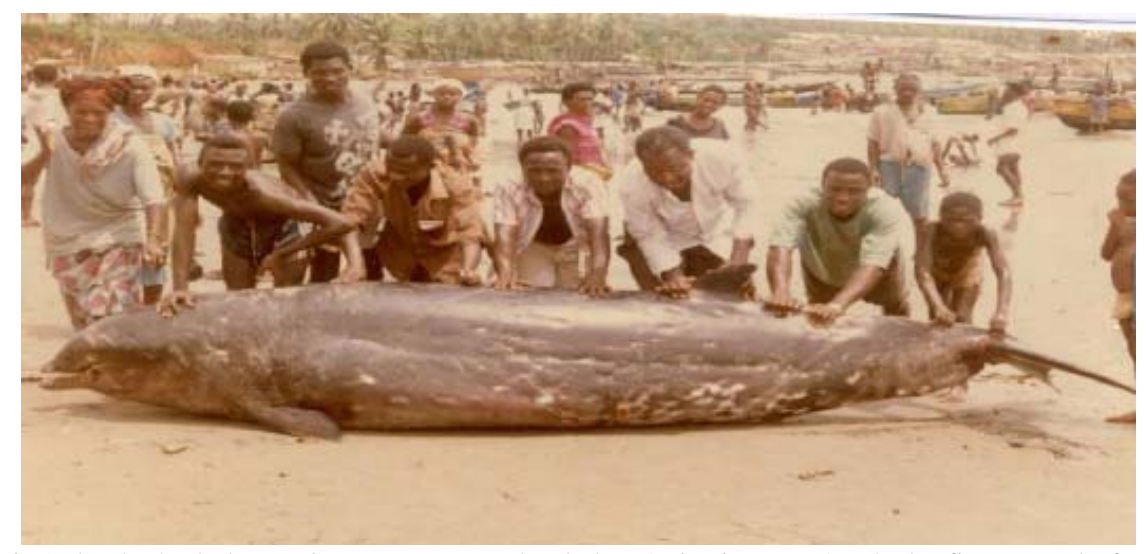

Fig. 15. A juvenile Cuvier's beaked whale, Ziphius cavirostris, landed at Axim in May 1994, the first record of a beaked whale in the Gulf of Guinea. Note the very short beak, the steeply sloped head, robust body and the dorsal fin located at 2/3 distance posteriorly.

(Photo courtesy D. Vanderpuje).

Distribution and natural history. Cuvier's beaked whale is a cosmopolitan pelagic species in tropical to warm temperate waters. Weir (2006b) described a group of three Cuvier's beaked whales southwest of Luanda, Angola, at $07^{\circ} 15.84^{\prime}$ S, $11^{\circ} 07.79^{\prime}$ E, and reported a group of 3-4 'likely Cuvier's beaked whales' NW of Luanda. Four other beaked whale sightings off Angola were not identified, but Z. cavirostris was possible in three cases, the fourth was a Mesoplodon sp. All encounters were over deep water seaward of the continental shelf (Weir, 2006b). Three stranded Cuvier's beaked whales are known from Namibia $\left(21^{\circ}-23^{\circ} \mathrm{S}\right)$ and another two from the Atlantic coast of South Africa (Findlay et al., 1992; Ross \& Tietz, 1972).

Conservation status. No information is available for West Africa. Worldwide, Z. cavirostris is characterized by a high degree of isolation and low maternal gene flow among oceanic populations (Dalebout et al., 2005). The single known capture of a Cuvier's beaked whale in Ghana among hundreds of other small cetaceans (Debrah, 2000; Ofori-Danson et al., 2003) suggests that impact from bycatch is negligible.

\section{Kogiidae}

\section{Dwarf sperm whale, Kogia sima}

Earliest documented record. Apam fishermen brought ashore a 120-cm dwarf sperm whale calf on 23 Aug 1998 (Fig. 16), the first evidence of this species for Ghana and the Gulf. One of the authors, Debrah, collected the skull for the UOG collection. Despite physical immaturity of the specimen, cranial characteristics including tooth counts (LL9, LR9, UL5, UR5) firmly identify it as K. sima, the only Kogia species that may bear teeth in the upper jaw (Caldwell \& Caldwell, 1989). In addition, the closely related pygmy sperm whale, K. breviceps, has more teeth (10-16 pairs) in the lower jaw.

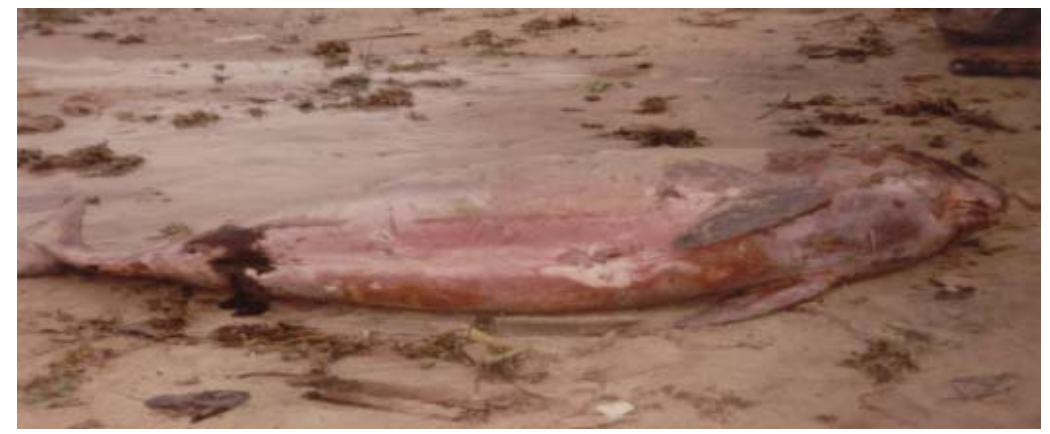

Fig. 16. A dwarf sperm whale, Kogia sima, landed as bycatch at Apam in 1998.

Distribution and natural history. Two unidentified Kogia sp. were photographed by fisheries observers, one at Shama in March 1994 and another at Apam on 10 April 2003. Unfortunately, ventral views do not allow species-level identification. No sightings exist for the Gulf. K. sima in South Africa is limited to the South Coast between Cape Columbine and about $28^{\circ}$ E. Stranded specimens of K. breviceps are recorded north to at least Cape Cross, Namibia, at $22^{\circ} \mathrm{S}$ (Ross, 1984; Ross et al., 1985; Findlay et al., 1992). Maigret \& Robineau (1981) reviewed the genus Kogia in Senegal and other countries in West Africa in some detail.

Conservation status. Although all three kogiid specimens validated for Ghana, one K. sima and two Kogia sp., were captured in drift gillnets, and potential impact of fisheries cannot yet be evaluated. The entanglement rate for kogiids seems low, but populations could also be small. 
Physeteridae

Sperm whale, Physeter macrocephalus

Earliest documented record. A sperm whale of some 7-9 m length (estimated from relative size of humans in photo) stranded at Osu beach, Accra, in July 1994 (Fig. 17). The cause of death was unknown and the only voucher data are three photographs. A second sperm whale, a decomposed shark-damaged carcass, stranded at Dixcove at an indeterminate date in 2002, is also supported by photographs. Both whales were of unknown sex.

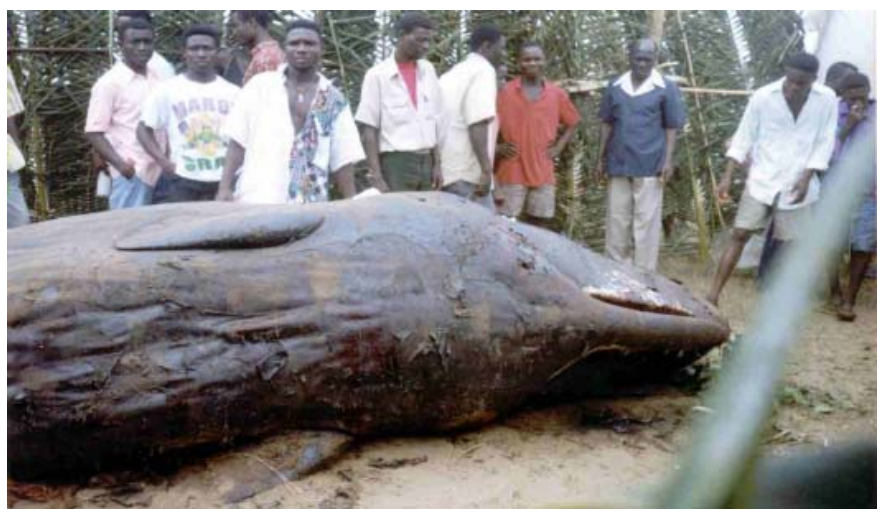

Fig. 17. A sperm whale, Physeter macrocephalus, stranded at Accra in Jul 1997 is the focus of a customary burial ceremony performed by local fishermen. Several (but not all) coastal communities in Ghana, Togo and Benin traditionally venerate whales and other cetaceans.

Distribution and natural history. Little scientific information is available for the Gulf of Guinea; however, females and juveniles are thought to be present year-round beyond the continental shelf. In Gabon, sperm whales were hunted from August till October (Slijper et al., 1964). Off Angola, their density peaked between January and May. Weir (2007) sighted sperm whales exclusively seaward of the shelf break and found them clustered particularly to the west of the Congo river mouth. Detailed natural history information is available only for sperm whales off the southwest coast of South Africa (e.g. Best 1967, 1969, 1970).

Conservation status. Sperm whales are 'vulnerable' according to the 2008 IUCN Red List and are listed in Appendix I of CMS. Long-line fishermen targeting tuna and sharks in equatorial waters of the Gulf, and farther south, complain about regular predation of hooked fish by sperm whales (Commandant Cosme Dossou, Port Maritime de Cotonou, Bénin, pers. comm. to Van Waerebeek, 24 August 2007).

\section{Balaenopteridae}

Humpback whale, Megaptera novaean-gliae

Earliest documented records. Irvine (1947) recorded seeing a whale which looked like a humpback whale at Prampram in September 1938; however, the species was not authenticated until Van Waerebeek \& OforiDanson (1999) presented a photo of a neonate (Fig. 18) stranded at Ada (05 48.5' N, 00 38' E) in Sept 1997, photo-graphed by a Ghana Wildlife Department officer. The emaciated calf showed no external trauma, and must have been either ill or unable to suckle. Another neonate stranded in Lomé, Togo, near the eastern border of Ghana, on 22 Aug 2005 (Tchibozo \& Van Waerebeek, 2007). The neonates, both very fresh (condition 2) when photographed, may have stranded alive. It is unknown whether the carcasses were utilized by locals. An adult-sized (estimated $12 \mathrm{~m}$ ) humpback whale stranded at Ada Foah (05 46' 33.15' N, $0^{\circ} 36^{\prime}$ 58.86’ E) on 18 Oct 2006 (Phillip Allman, pers. comm. to Van Waerebeek, email 28.08.2008). Allman's photographs show a condition-3 carcass. A humpback whale was sighted from Fort Iron Cross, Dixcove, breaching repeatedly at $c a .1 \mathrm{~km}$ from shore on 24 Sept 2008. The curator had seen several humpback whales 'much closer inshore' the day before (23 September), and added he very commonly observed humpback whales from September till December but not in other months, since 1978. 


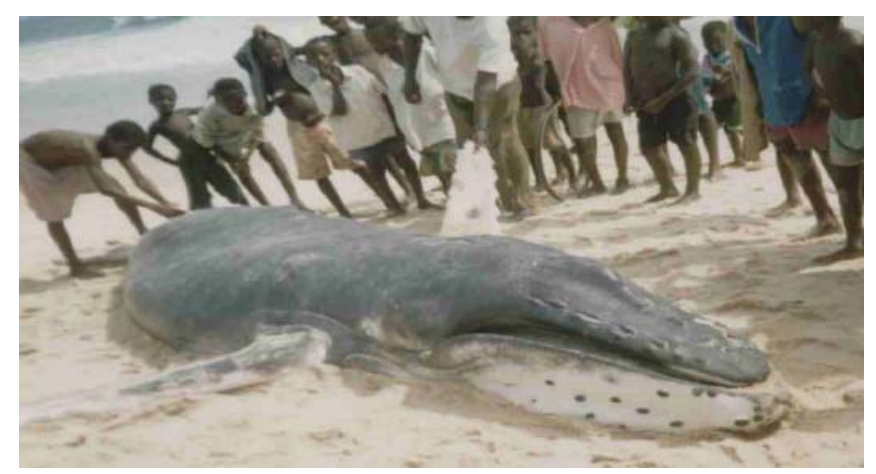

Fig. 18. An emaciated neonate humpback whale stranded at Ada, eastern Ghana, in Sept 1997. Photographed when freshly dead, it is unclear whether the animal died on the beach. Ghana's coast forms part of the distribution range of a 'Gulf of Guinea' breeding stock, whose calving seasonality and exclusive presence in austral winter months firmly points toward a Southern Hemisphere population.

Distribution and natural history. Rasmussen et al. (2007) encountered several humpback whale pods (fluke photo-ID taken for two individuals) including a mother and possible newborn calf in Ghanaian waters between 04' 02.676" N, 01' 56.015" W and 04' 54.402" N, 00' 35.895" W on 1 and 2 Oct 2006. Considering the exclusive presence of humpback whales from early August till late November, and the frequent observations of neonates and 'competitive groups' (Clapham, 2002), it is evident that the continental shelf of Benin, Togo, Ghana, and western Nigeria hosts a breeding/calving population with a Southern Hemisphere seasonality (Van Waerebeek et al., 2001) for which the authors propose the name 'Gulf of Guinea stock'. Its parapatric distribution suggests it may be related to the IWC-defined breeding stock ' $\mathrm{B}$ ' from central-west Africa (IWC, 1998, 2006). Mother/calf pairs have been sighted exclusively nearshore in Benin, sometimes just beyond the surf-zone. The westernmost authenticated record is a stranding at Assini Mafia $\left(05^{\circ} 7^{\prime} 25^{\prime \prime} \mathrm{N}\right.$, 03 16’40" W), eastern La Côte d'Ivoire, on 26 Aug 2007 (Van Waerebeek et al., 2007).

For many years, small-scale humpback whale-watching operations have been conducted seasonally from the ports of Sekondi-Takoradi, Lomé and Cotonou, evidencing commercially viable encounter rates (Van Waerebeek et al., 2001). Tim Dodman (pers. comm. in email to Van Waerebeek, 6 Oct 2005) sighted an adult with calf off the east coast of São Tomé on 14 Sept 2005, and Bill Axon, master of the MV Pacific Banner, reported (email to Nicola Hodgins, 2 Aug 2008) hourly sightings of pods of 2-3 adult whales, occasionally adults with 'juveniles' (probably calves) near the Okume \& Ceiba oil field, at $01^{\circ} 24.3^{\prime} \mathrm{N}, 09^{\circ} 14.0^{\prime} \mathrm{E}$, Equatorial Guinea. Descriptions and a sketch confirmed that these were humpback whales. The breeding stock off Gabon is the subject of intensive molecular genetic and ecological studies (e.g. Walsh et al., 2000; Rosenbaum et al., 2004; Rosenbaum \& Collins, 2004).

Conservation status. No abundance estimate is available yet for the Bight of Benin population but encounter rate in October 2000 was 0.109 humpback whales/nmile surveyed (Van Waerebeek et al., 2001). The reported neonates stranded in unknown circumstances and both natural and anthropogenic causes are possible. At least some (adult) humpback whale strandings in the area are thought to be animals killed in vessel collisions, which may be far more common in African waters than scarce reports suggest (Félix \& Van Waerebeek, 2005; Van Waerebeek et al., 2007; Best, 2007). For instance, the humpback whales sighted less than $1 \mathrm{~km}$ off Cotonou's harbour entrance in the main shipping lanes incurred obvious risk. The individual that stranded at Assini Mafia was reported with external trauma consistent with a propeller hit (Van Waerebeek et al., 2007).

\section{Results and discussion}

Specimen evidence derived from fisheries interactions and strandings, and a few sightings presented in this paper show that the cetacean fauna of Ghana is moderately diverse, essentially tropical and comprises predominantly pelagic but also some neritic elements. Ghana's cetacean faunistic list includes 17 species and five families, of which are 13 Delphinidae, and one each of Ziphiidae, Physeteridae, Kogiidae and Balaenopteridae. While several had been named for Ghana in various reports in recent years, nine species are here authenticated for the first time, including three (Peponocephala electra, Kogia sima, Ziphius cavirostris), which have not previously been reported from the Gulf of Guinea. Continued port monitoring and, hopefully, boat surveys should reveal additional species in the future.

Some authors (Perrin et al., 1994; Jefferson et al., 1997) referred to Wilson et al. (1987) for a striped dolphin, Stenella coeruleoalba, record from La Côte d'Ivoire but no voucher material is identifiable. However, striped dolphin sightings are not uncommon over deep water off Angola (Weir, 2007), and this 
delphinid may be present in the Gulf beyond the shelf zone. Gervais' beaked whale, Mesoplodon europaeus, has been documented from Ascension to the south and Guinea-Bissau to the west (Rice, 1998). Pantropical cetaceans like the pygmy sperm whale, Kogia breviceps, and Blainville's beaked whale, Mesoplodon densirostris, are expected to at least occasionally enter Ghana's EEZ waters. These species have a general pelagic distribution which would effectively shield them from entanglement in artisanal gillnets set in more coastal waters. Bryde's whales, Balaenoptera brydei, originally described from South Africa (Olsen, 1913), were taken as far north as Gabon (Ruud, 1952).

Regular landings in several ports of S. clymene, S. attenuata, T. truncatus and, to a lesser degree, G. griseus, S. frontalis, S. bredanensis, G. macrorhynchus and P. electra suggest that these delphinids are fairly common in Ghana's waters, although any quantitative indication of population abundance is lacking. Rarely captured species may have lower abundance, at least near the continental shelf and slope, or may be more wary of nets. Landed cetaceans as a rule are utilized as 'marine bushmeat' (Clapham \& Van Waerebeek, 2007), defined as meat and other edible parts derived from wild-caught marine mammals, sea turtles and seabirds. Debrah (2000) and Ofori-Danson et al. (2003) discussed aspects of dolphin exploitation in Ghana for the period 1998-2000.

Remarkably, Sousa teuszii has so far not been recorded in Ghana, Togo, Benin, Nigeria or La Côte d'Ivoire (Debrah, 2000, Ofori-Danson et al., 2003, Van Waerebeek et al., 2004, Perrin \& Van Waerebeek, 2007) despite apparently suitable coastal habitat. Also, since the holotype was collected in the port of Douala (Kükenthal, 1892), not a single new record has emerged from Cameroon. Possible explanations may include local extirpation through intense pressure from coastal fisheries (bycatch), disturbance and other habitat encroachment, or insufficient research effort. Unconfirmed fishermen's reports that humpback dolphins are occasionally seen between the Volta River delta (eastern Ghana) and Lomé, Togo, should be verified. In recent years Atlantic humpback dolphins have been encountered with some regularity in Gabon (Schepers \& Marteijn, 1993; Collins et al., 2004; Van Waerebeek et al., 2004).

The occurrence of $D$. capensis in Ghana (this paper), La Côte d'Ivoire (Cadenat, 1959) and Gabon (Van Waerebeek, 1997) points to a wide distribution in the Gulf. In the eastern Pacific, $D$. capensis occupies the coastal upwelling systems of the cool Humboldt and California Currents as its core habitat, whereas $D$. delphis is distributed in more pelagic waters (e.g. Heyning \& Perrin, 1994; Van Waerebeek et al., 1994; Sanino et al., 2003). This raises the question whether in the Gulf of Guinea $D$. capensis may partly relate to the seasonal upwelling over the continental shelf (Adamec \& O'Brien, 1978). The listing of $D$. delphis in Ofori-Danson et al. (2003, Table 2) was premature, but the species may be present offshore. The skull of a confirmed D. delphis was collected at Gabon's port Mayoumba (van Bree \& Purves, 1972; Van Waerebeek, 1997), presumably from a bycatch.

The present checklist underscores the fact that knowledge of the distribution, natural history, population structure and ecology of dolphins and whales in Ghana and the Gulf of Guinea, while advancing, is still rudimentary. Considering the current availability of fresh carcasses of small cetaceans in Ghana's fishing ports, a more exhaustive research and sampling programme could vastly improve the state of knowledge over a relatively short period but would require the supply of adequate resources to train local scientists in appropriate institutions.

\section{Acknowledgement}

P. Allman, B. Axon, T. Dodman, N. Eriksen, C. Gordon, J. G. Mead, Ofori-Adu, C. Potter, M.H. Rasmussen and D. Vanderpuje are warmly thanked for access to unpublished photographs, records or specimens in their care. The authors are very grateful to Ghana fisheries observers, Samuel Botwe, Samuel Ebo, Samuel Kojo Odoom, Benjamin K. Otoo, and, in particular, to E. Amiah Johnson, for their hard work and dedication. They are much indebted to W.F. Perrin for critically reading an earlier draft and providing excellent remarks. Data were generated through various projects over several years (1998-2003) and field work was supported by a number of organisations: CMS/UNEP (WAFCET-3 Project), International Fund for Animal Welfare, Leopold III Fonds voor Natuuronderzoek en Natuurbehoud, Marine Education and Research, Whale and Dolphin Conservation Society, WWF-International, Colombus Zoological Park Association and Chicago Zoological Society.

\section{References}

Adamec D. and O’Brien J. J. (1978). The seasonal upwelling in the Gulf of Guinea due to remote forcing. J. Phys. Oceanog. 8: 1050-1060.

Armah A. K., Darpaah G. A. and Wiafe G. (1996). Managing the Coast of Ghana: problems and options. In The coastal zone of Africa: problems and management. (S. M. Evans, C. J. Vanderpuye and A. K. Armah, ed.). Penshaw Press. 246 pp.

West African Journal of Applied Ecology, vol. 15, 2009 
Bamy I. L., Van Waerebeek K., Bah S. S., Dia M., Kaba B., Keita N., Konate S. and Tall H. (2006). The cetaceans of Guinea, a first check-list of documented species. Paper SC/58/O15 presented to 58th Meeting of IWC Scientific Committee, St Kitts, MayJune 2006. 7pp. IWC Secretariat, Cambridge, UK.

Best P. B. (1967). The sperm whale (Physeter catodon) off the West coast of South Africa. 1. Ovarian changes and their significance. Invest. Rep. Div. Sea Fish. S. Afr. 61: 1-27.

Best P. B. (1969). The sperm whale (Physeter catodon) off the West coast of South Africa. 4. Distribution and movements. Invest. Rep. Div. Sea Fish. S. Afr. 78:1-12.

Best P. B. (1970) The sperm whale (Physeter catodon) off the West coast of South Africa. 5. Age, growth and mortality. Invest. Rep. Div. Sea Fish. S. Afr. 61:1-27.

Best P. B. (1994). A review of the catch statistics for modern whaling in southern Africa, 1908-1930. Rep. Int. Whal. Comm. 44: 467485.

Best P. B. (2007). Whales and Dolphins of the Southern African Subregion. Cambridge University Press. Cape Town, South Africa. $336 \mathrm{pp}$.

Best P. B., Reeb D., Morais M. and Baird A. (1999). A preliminary investigation of humpback whales off Northern Angola. Paper SC/51/CAWS33 presented to IWC Scientific Committee, Grenada, May 1999. 9 pp.IWC Secretariat, Cambridge, UK.

Best P. B. and Ross G. J. B. (1977). Exploitation of small cetaceans off Southern Africa. Rep. Int. Whal. Comm. 34: $494-497$.

Best P. B. and Ross G. J. B. (1984). Live-capture fishery for small cetaceans in South African waters. Rep. Int. Whal. Comm. 34: 615-618.

Best P. B. and Shaughnessy P. D. (1981). First record of the melon-headed whale, Peponocephala electra from South Africa. Ann. S. Afr. Mus. 83(3): 33-47.

Broekema J. W. (1983). Catalogue of cetacea in the collection of the Rijksmuseum van Natuurlijke Historie, Leiden. Zool. Meded. 57: 67-79.

Budker P. (1951). L’industrie baleinière au Gabon. Bull. Soc. Zool. France 76: 271-276.

Budker P. (1953). Les campagnes baleinières 1949-1952 au Gabon (Note préliminaire). Mammalia 17(3): 129-148.

Cadenat J. (1959a). Notes sur les Delphinidés Ouest-africains. VI. Le gros dauphin gris (Tursiops truncatus) est-il capable de faire des plongées profondes ? Bull. IFAN 22A (3): 1137-1141.

Cadenat J. (1959b). Rapport sur les petits cétacés ouest-Africains. Résultats des recherches entreprises sur ces animaux jusqu'au mois de mars 1959. Bull. IFAN 21A (4): 1367-1409.

Cadenat J. and Lassarat A. (1959a). Notes sur les Delphinidés ouest-africains. III. Notes complémentaires sur Tursiops truncatus. Bull. IFAN 21A (1): 416-419.

Cadenat J. and Lassarat A. (1959b). Notes sur les Delphinidés ouest-africains. IV. Sur un Prodelphinus indéterminé de Côte d'Ivoire. BulI. IFAN 21A (2): 777-786.

Caldwell O. K. and Caldwell M. C. (1989). Pygmy sperm whale Kogia breviceps (de Blainville, 1838): dwarf sperm whale Kogia simus Owen, 1866. In Handbook of Marine Mammals. (S. H. Ridgway and R. Harrison, ed.), pp. 235-260. Academic Press. 442 pp.

Carwardine M. (1994). On the trail of the whale. Thunder Bay Publishing Co., Guilford, Surrey, UK. 158 pp.

Clapham P. (2002). Humpback whale Megaptera novaeangliae. In Encyclopedia of Marine Mammals. (W.F. Perrin, B. Würsig and J. G. M. Thewissen, ed.), pp. 589-592. Academic Press.

Clapham P. and Van Waerebeek K. (2007). Bushmeat, the sum of the parts. Mol. Ecol. 16: 2607-2609.

Collins T., Ngouessono S. and Rosenbaum H. C. (2004). A note on recent surveys for Atlantic humpback dolphins, Sousa teuszii (Kükenthal, 1892) in the coastal waters of Gabon. Paper SC/56/SM23 presented to International Whaling Commission Annual meeting. IWC Secretariat, Cambridge, UK.

Dalebout M. L., Robertson K. M., Frantzis A., Engelhaupt D., Mignucci-Giannoni A. A., Rosario-Delestre R. J. and Baker C. S. (2005). Worldwide structure of mtDNA diversity among Cuvier's beaked whales (Ziphius cavirostris): implications for threatened populations. Mol. Ecol. 14: 3353-3371.

Debrah J. S. (2000). Taxonomy, exploitation and conservation of dolphins in the marine waters of Ghana. (MPhil. Thesis.) Department of Oceanography and Fisheries, University of Ghana, Legon. 86 pp.

Donahue M. A. and Edwards E. F. (1996). An annotated bibliography of available literature regarding cetacean interactions with tuna purse-seine fisheries outside of the Eastern Tropical Pacific Ocean. NOAA Administrative Report LJ-96-20.

FAO (1997). El Estado Mundial de la Pesca y la Acuicultura 1996. Departamento de Pesca de la FAO, Roma. 125 pp.

Félix F. and Van Waerebeek K. (2005). Whale mortality from ship strikes in Ecuador and West Africa. LAJAM 4 (1): 55-60.

Findlay K. P., Best P. B., Ross G. J. B. and Cockroft V. G. (1992). The distribution of small odontocete cetaceans off the coasts of South Africa and Namibia. S. Afr. J. Mar. Sci. 12: 237-270.

Fonteneau A. and Marcille J. (ed.) (1993). Resources, fishing and biology of the tropical tunas of the Eastern Central Atlantic. FAO Fish. Tech. Paper 292.

Fraser F. C. (1950a). Description of a dolphin Stenella frontalis (Cuvier) from the coast of French Equatorial Africa. Atlantide Reports 1: 61-84.

Fraser F. C. (1950b). Two skulls of Globicephala macrorhyncha (Gray) from Dakar. Atlantide Reports 1: 49-60.

Geraci J. R. and Lounsbury V. J. (1993). Marine Mammals Ashore. A Field Guide for Strandings. Texas A\&M University Sea Grant College Program. 305 pp.

Gray J. E. (1828). Original figures and short systematic descriptions of new and unfigured animals. Spicilegia Zoologica 1: 1-2.

Hammond P. S. and Lockyer C. (1988). Distribution of killer whales in the eastern North Atlantic. Rit Fiskideildar 11: 24-35.

Heimlich-Boran S. (1990). Pilot study. Sonar 4: 6-8.

Hershkovitch P. (1966). Catalog of Living Whales. Bulletin 246, Smithsonian Institution, Washington. 259 pp.

Heyning J. E. and Perrin W. F. P. (1994). Evidence for two species of common dolphins (Genus Delphinus) from the eastern North Pacific. Contr. Sci. 442: 1-35.

Irvine F. R. (1947). The Fish and Fisheries of the Gold Coast. Her Majesty Service, Gold Coast.

International Hydrographic Organization (1953). Limits of Oceans and Seas. Special Publication No. 28. Imprimérie Monégasque, Monte-Carlo. 
IWC (1975). Report of the Meeting on Smaller Cetaceans, Montreal, Apr 1-11, 1974. (ed. E. Mitchell). J. Fish. Res. Board Can. 32(7): 889-983.

IWC (1994). Report of the Workshop on mortality of cetaceans in passive fishing nets and traps. Rep. Int. Whal. Comm. (Special issue 15): 629 pp.

IWC (1998). Initial alternative hypotheses for the distribution of humpback breeding stocks on the feeding grounds. Rep. Int. Whal. Comm. 48: 181.

IWC (2006). Annex H. Report of the sub-committee on the other Southern Hemisphere whale stocks. J. Cet. Res. Mgmt (Suppl.) 8: $151-170$

Jefferson T. A. and Barros N. B. (1997). Peponocephala electra. Mamm. Spec. 553: 1-6.

Jefferson T. A. (2002). Clymene dolphin Stenella clymene. In Encyclopedia of Marine Mammals. (W. F. Perrin, B. Würsig and J. G. M. Thewissen, ed.), pp. 234-236. Academic Press.

Jefferson T. A., Curry B. E., Leatherwood S. and Powell J. A. (1997). Dolphins and porpoises of West Africa: a review of records (Cetacea: Delphinidae, Phocoenidae). Mammalia 61: 87-108.

Jefferson T. A. and Van Waerebeek K. (2002). The taxonomic status of the nominal dolphin species Delphinus tropicalis van Bree, 1971. Mar. Mam. Sci. 18(4): 1-32.

Koranteng K. A. (2001). Structure and dynamics of demersal assemblages on the continental shelf and upper slope off Ghana, West Africa. Mar. Ecol. Progr. Ser. 220: 1-12.

Koranteng K. A., Nmashie O. O. and Baddoo A. (1993). Ghana Canoe Frame Survey 1992. Fisheries Department, Ministry of Food and Agriculture, Accra, Ghana. 48 pp.

Kükenthal W. (1892). Sotalia teuszii n.sp. eine pflanzenfressender (?) Delphin aus Kamerun. Zool. Jahrbücher Abt. Syst. 6: $442-446$.

Leatherwood S., Caldwell O. K. and Winn H. E. (1976). Whales, dolphins and porpoises of the western North Atlantic. A guide to their identification. NOAA Tech. Rep. NMFS Circular 396. 176 pp.

Maigret J. (1981). Données nouvelles sur l'écologie du Sousa teuszii (Cetacea, Delphinidae) de la Côte ouest Africaine. Bull. IFAN 42A: 619-33.

Maigret J. (1981). Rapports entre les cétacés et la pêche thonière dans l’Atlantique tropical oriental. Notes afr. 171: 75-84.

Maigret J. (1994). Marine Mammals and Fisheries along the West African Coast. Rep. Int. Whal. Comm. Special issue 15: 307-328.

Maigret J. and Robineau D. (1981). Le genre Kogia (Cetacea, Physeteridae) sur les côtes du Sénégal. Mammalia 45(2): 199-204.

Mitchell E. (1975). Porpoise, dolphin and small whale fisheries of the world. IUCN Monog. 3: 1-129.

Mitchell E. (ed.) (1975). Report of the meeting on smaller cetaceans, Montreal, April 1-11, 1974. J. Fish. Res. Board Can. 32: 889983.

Mörzer Bruyns W. F. J. (1969). Sight records and notes on the false killer whale, Pseudorca crassidens (Owen, 1846). Säugetierk. Mitteil. 17: 351-356.

Nieri M., Grau E., Lamarche B. and Aguilar A. (1999). Mass mortality of Atlantic spotted dolphins (Stenella frontalis) caused by a fishing interaction in Mauritania. Mar. Mamm. Sci. 15(3): 847-854.

Northridge S. P. (1984). World review of interactions between marine mammals and fisheries. FAO Fish. Tech. Paper 251, 190 pp.

Northridge S. P. (1996). A review of marine mammal bycatch observer schemes with recommendations for best practice. Joint Nature Conservation Committee Report, No. 219. Aberdeen, UK. 42 pp.

Ofori-Adu D. W. (1987). On some marine mammals likely to be found in the Ghanaian coastal waters. Fish. Res. Unit Inform. Rep. 20. 19 pp.

Ofori-Adu D. W. and Koranteng K. A. (1993). Occurrence of demersal fish species off Winneba and Saltpond. Their abundance and distribution in relation to the marine environment. Mar. Fish. Res. Rep. 9: 1-88.

Ofori-Danson P. K. and Agbogah K. (1995). Survey of aquatic mammals of Ghana. A report presented to the Oceans and Coastal Areas, Programme Activity Centre (OCA/PAC) of the United Nations Environment Programme. Institute of Aquatic Research, Tech. Rep. 143.

Ofori-Danson P. K. and Odei M. A. (1997). Preliminary observations of the common dolphin, Delphinus delphis, (Order: Cetacea; fam: Delphinidae) in the Ghanaian coastal waters. Paper SC/49/SM3 presented to IWC Scientific Committee, Bournemouth, UK. [available from the IWC Secretariat].

Ofori-Danson P. K., Van Waerebeek K. and Debrah S. (2003). A survey for the conservation of dolphins in Ghanaian coastal waters. J. Ghana Sci. Assoc. 5 (2): 45-54.

Perrin W. F. (1990). Subspecies of Stenella longirostris (Mammalia: Cetacea, Delphinidae). Proc. Biol. Soc. Wash. 103 (2): $453-$ 463.

Perrin W. F. (2004). Chronological bibliography of the tuna-dolphin problem, 1941-2001. NOAA Tech. Mem. NMFS-SWFSC 356.

Perrin W. F., Mitchell E. D., Mead J. G., Caldwell D. K. and van Bree P. J. H. (1981). Stenella clymene, a rediscovered tropical dolphin of the Atlantic. J. Mamm. 62(3): 583-598.

Perrin W. F., Mitchell E. D., Mead J. G., Caldwell D. K., Caldwell M. C., van Bree P. J. H. and Dawbin W. H. (1996). Revision of the spotted dolphins Stenella spp. Mar. Mamm. Sci. 3: 99-170.

Perrin W. F. and Van Waerebeek K. (2007). The small-cetacean fauna of the west coast of Africa and Macaronesia: diversity and distribution. UNEP/CMS-WATCH-Inf.6. CMS, Bonn.

Pitman R. L. and Ensor P. (2003). Three forms of killer whales in Antarctic Waters. J. Cet. Res. Mgmt. 5:131-139.

Rasmussen M. H., Tougaard J., Eriksen N., Miller L. A., Teilmann J., Kyhn L. and Wahlberg M. (2007). Sound recordings and sightings of Cetaceans during the Danish round the world “Galathea3" Expedition. Poster presented to The Society for Marine Mammalogy Biennial Conference on the Biology of Marine Mammals, Cape Town, South Africa, 29 November-3 December 2007.

Reeves R. and Mitchell E. (1988). Killer whale sightings and takes by American pelagic whalers in the North Atlantic. Rit Fiskideildar 11: 7-23.

Rice D. W. (1998). Marine Mammals of the World. Systematics and Distribution. Special Publication 4. The Society for Marine Mammalogy. 231 pp. 
Robineau D., Vély Y. M. and Maigret J. (1994). Stenella clymene (Cetacea, Delphinidae) from the coast of West Africa. J. Mamma. 75(3): 766-767.

Rosenbaum H. C., Pomilla C., Leslie M., Best P. B., Collins T., Engel M. H., Ersts P. J., Findlay K. P., Kotze P. J. H., Meyer M., Minton G., Barendse J., Van Waerebeek K. and Razafindrakoto Y. (2004). Mitochondrial DNA diversity and population structure of humpback whales from their wintering areas in the Indian and South Atlantic Oceans (Wintering Regions A, B, C and X). Paper SC/56/SH3 presented to IWC Scientific Committee, July 2004, Sorrento, Italy. IWC Secretariat, Cambridge, UK.

Rosenbaum H. C. and Collins T. (2004). Cetacean Conservation and Research in Gabon: 2000-2004. Wildlife Conservation Society, Bronx, NY. 56 pp.

Ross G. J. B. (1977). The taxonomy of bottlenosed dolphins Tursiops species in South African waters, with notes on their biology. Ann. Cape Prov. Mus. (Nat. Hist.) 11(9): 135-194.

Ross G. J. B. (1984). The smaller cetaceans of the southeast coast of southern Africa. Ann. Cape Prov. Mus. (Nat. Hist.) 15: 173-410.

Ross G. J. B., Cockcroft V. G. and Cliff G. (1985). Additions to the marine mammal faunas of South Africa and Natal. Lammergeyer 35: 36-40.

Ross G. J. B. and Tietz R. M. (1972). Records of Cuvier's beaked whale, Ziphius cavirostris, from southern Africa. Ann. Cape Prov. Mus. (Nat. Hist.) 9(1): 1-10.

Ruud J. T. (1952). Catches of Bryde-whale off French Equatorial Africa. Norsk Hvalfangst 41(12): 662-663.

Samaai T., Best P. B. and Gibbons M. J. (2005). The taxonomic status of common dolphins Delphinus spp. in South African waters. Afr. J. Mar. Sci. 27(2): 449-458.

Sanino G. P., Van Waerebeek K. and Yañez J. (2003). Revisión de la distribución del género Delphinus y primeros registros documentados de Delphinus capensis en Chile. Bol. Museo Nac. Hist. Nat. Chile 52: 97-102.

Slijper E. J., Van Utrecht W. L. and Naaktgeboren C. (1964). Remarks on the distribution and migration of whales, based on observations from Netherlands ships. Bijdr. Dierk. 34: 3-93.

Schepers F. J. and Marteijn E. C. L. (ed.) (1993). Coastal waterbirds in Gabon, winter 1992. Foundation Working Group International Wader and Waterfowl Research. WIWO Report 41. Zeist, The Netherlands. 293 pp.

Tchibozo S. and Van Waerebeek K. (2007). La baleine à bosse et le lamantin d'Afrique, des potentielles ressources de tourisme de la nature au Bénin. Abstract presented at the CMS/WATCH Meeting, Adeje, Tenerife, 16-20 October 2007. CMS Secretariat, Bonn, Germany.

Tormosov D. D., Budylenko G. A. and Sazhinov E. G. (1980). Biocenological aspects in the investigations of sea mammals. International Whaling Commission Document SC/32/02. 8 pp. IWC Secretariat, Cambridge, UK.

van Bree P. J. H. (1971). On skulls of Stenella longirostris (Gray, 1828) from the eastern Atlantic (Notes on Cetacea, Delphinoidea IV). Beaufortia 19: 21-25.

van Bree P. J. H. (1972). Sur la présence de Pseudorca crassidens (Owen, 1846) [Cetacea, Globicephalinae] au large des côtes d'Afrique occidentale. Bull. IFAN. 34, ser. A 1: 212-218.

van Bree P. J. H., Best P. and Ross G. J. B. (1978). Occurrence of the two species of pilot whales (genus Globicephala) on the coast of South Africa. Mammalia 42(3): 323-328.

van Bree P. J. H. and Purves P. E. (1972). Remarks on the validity of Delphinus bairdii (Cetacea, Delphininae). J. Mammal. 53: 372-374.

van Bree P. J. H. and Cadenat J. (1968). On a skull of Peponocephala electra (Gray, 1846) (Cetacea, Globicephalinae) from Senegal. Beaufortia 14: 193-202.

Van Waerebeek K. (1997). Long-beaked and short-beaked common dolphins sympatric off central-west Africa. Paper SC/49/SM46 presented to the Scientific Committee of the International Whaling Commission. 5 pp. IWC Secretariat, Cambridge, UK.

Van Waerebeek K. (2003). A newly discovered stock of humpback whales in the northern Gulf of Guinea. CMS Bull. 18: 6-7.

Van Waerebeek K. (2007). Conservation status of the Clymene dolphin in West Africa. Document CMS/ScC14/Doc.5 presented to 14th Meeting of the CMS Scientific Council.CMS/UNEP Secretariat, Bonn.

Van Waerebeek K. and De Smet W. M. A. (1996). A second confirmed record of the false killer whale Pseudorca crassidens (Owen, 1846) (Cetacea, Delphinidae) from West Africa. Mammalia 60 (2): 319-322.

Van Waerebeek K. and Ofori-Danson P. K. (1999). A first checklist of cetaceans of Ghana, Gulf of Guinea, and a shore-based survey of interactions with coastal fisheries. Paper SC/51/SM35 presented to 51st Meeting of the IWC Scientific Committee, May 1999, Grenada. 9 pp. IWC Secretariat, Cambridge, UK.

Van Waerebeek K., Ofori-Danso P. K., Ofori-Adu D. and Debrah J. (1999). Asynoptic surveyof cetaceans and their unteractions with fisheries in Ghana, Togo and Benin. Progress Report prepared for the Internal Fund for Animal Welfare. Environmental Department, University of Ghana, Legon. 10 pp.

Van Waerebeek K., Ndiaye E., Djiba A., Diallo M., Murphy P., Jallow A., Camara A., Ndiaye P. and Tous P. (2000). A survey of the conservation status of cetaceans in Senegal, The Gambia and Guinea-Bissau. UNEP/CMS Secretariat, Bonn, Germany. 80 pp.

Van Waerebeek K., Tchibozo S., Montcho J., Nobime G., Sohou Z., Sohouhoue P. and Dossou C. (2001). The Bight of Benin, a North Atlantic breeding ground of a Southern Hemisphere humpback whale population, likely related to Gabon and Angola substocks. Paper SC/53/IA21 presented to the Scientific Committee of the International Whaling Commission, London, July 2001. 8 pp. (Available from the IWC Secretariat, Cambridge, UK).

Van Waerebeek K., Barnett L., Camara A., Cham A., Diallo M., Djiba A., Jallow A. O., Ndiaye E., Samba Ould Billal A. O. and Bamy I. L. (2004). Distribution, status and biology of the Atlantic humpback dolphin Sousa teuszii (Kükenthal, 1892). Aq. Mamm. 30(1): 56-83.

Van Waerebeek K., Baker A. N., Félix F., Gedamke J., Iñiguez M., Sanino G. P., Secchi, E., Sutaria D., van Helden A., and Wang Y. (2007). Vessel collisions with small cetaceans worldwide and with large whales in the Southern Hemisphere, an initial assessment. LAJAM 6(1): 43-69.

Van Waerebeek K., Van Bressem M. F., Reyes J.C., Alfaro J. A., Bello R., Echegaray M., García-Godos A. and Ontón K. (1994). Illegal exploitation of small cetaceans in Peru. Final report to United Nations Environment Programme, Nairobi, Kenya and WDCS, UK. $76 \mathrm{pp}$.

West African Journal of Applied Ecology, vol. 15, 2009 
Van Waerebeek, K., Bamy, I. L., Jiddou, A. M., Sequeira, M., Diop, M., Ofori-Danson, P. K., Tchibozo, S. and Campredon, P. (2008). Indeterminate status of West African populations of inshore common bottlenose dolphins Tursiops truncatus cautions against opportunistic live-capture schemes. Technical Report to the Fondation Internationale du Banc d'Arguin (FIBA). 9 pp. (Available from www.lafiba.org).

Walsh P. D., Fay J. M., Gulick S. and Sounguet P. (2000). Humpback whale activity near Cap Lopez, Gabon. J. Cet. Res. Mgmt 2(1): 63-67.

Weigel J. Y. (1984). Le secteur de la pêche, situation actuelle et perspective. Doc. Polygr. Lomé, Togo.

Weir C. R. (2006a). First confirmed records of Clymene dolphin Stenella clymene (Gray, 1850) from Angola and Congo, south-east Atlantic Ocean. Afr. Zool. 41(2): 297-300.

Weir C. R. (2006b). Sightings of beaked whales (Cetacea: Ziphiidae) including first confirmed Cuvier's beaked whales Ziphius cavirostris from Angola. Afr. J. Mar. Sci. 28: 173-175.

Weir C. R. (2007). The distribution and seasonal occurrence of cetaceans off northern Angola. J. Cet. Res. Mgmt 9(3): 225-239.

Weir C. R. (2008). Overt responses of humpback whales (Megaptera novaeangliae), sperm whales (Physeter macrocephalus), and Atlantic spotted dolphins (Stenella frontalis) to seismic exploration off Angola. Aq. Mamm. 34(1): 71-83.

Weir C. R., Debrah J., Ofori-Danson, P. K., Pierpoint C. and Van Waerebeek K. (2008). Records of Fraser's dolphin Lagenodelphis hosei Fraser, 1956 from the Gulf of Guinea and Angola. Afr. J. Mar. Sci. 30(2): 241-246.

Wilson C. E., Perrin W. F., Gilpatrick J. W. Jr and Leatherwood S. (1987). Summary of worldwide locality records of the striped dolphin, Stenella coeruleoalba. US Department of Commerce, NOAA Tech. Mem. NMFS-TM-NMFS-SWFC-90. 65 pp.

Whitehead H. and Glass C. (1985). Orcas (killer whales) attack humpback whales. J. Mammal. 66(1): 183-185. 